\title{
Amelioration of marine environments at the Smithian-Spathian boundary, Early Triassic
}

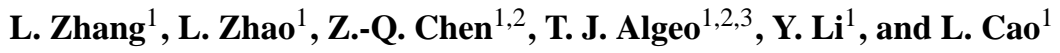 \\ ${ }^{1}$ State Key Laboratory of Geological Process and Mineral Resources, China University of Geosciences, 430074 Wuhan, China \\ ${ }^{2}$ State Key Laboratory of Biogeology and Environmental Geology, China University of Geosciences, 430074 Wuhan, China \\ ${ }^{3}$ Department of Geology, University of Cincinnati, Cincinnati, OH 45221, USA
}

Correspondence to: Z.-Q. Chen (zhong.qiang.chen@cug.edu.cn) and T. J. Algeo (algeot@ucmail.uc.edu)

Received: 30 September 2014 - Published in Biogeosciences Discuss.: 6 November 2014

Revised: 31 January 2015 - Accepted: 3 February 2015 - Published: 12 March 2015

\begin{abstract}
The protracted recovery of marine ecosystems following the Permian-Triassic mass extinction may have been caused, in part, by episodic environmental and climatic crises during the Early Triassic, among which the SmithianSpathian boundary (SSB) event is conspicuous. Here, we investigate the SSB event in the Shitouzhai section, Guizhou Province, South China, using a combination of carbonate carbon $\left(\delta^{13} \mathrm{C}_{\text {carb }}\right)$ and carbonate-associated sulfate sulfur isotopes $\left(\delta^{34} \mathrm{~S}_{\mathrm{CAS}}\right)$, rare earth elements, and elemental paleoredox and paleoproductivity proxies. The SSB at Shitouzhai is characterized by a $+4 \%$ shift in $\delta^{13} \mathrm{C}_{\text {carb }}$ and a -10 to $-15 \%$ o shift in $\delta^{34} \mathrm{~S}_{\mathrm{CAS}}$, recording negative covariation that diverges from the positive $\delta^{13} \mathrm{C}_{\mathrm{carb}}-\delta^{34} \mathrm{~S}_{\mathrm{CAS}}$ covariation that characterizes most of the Early Triassic. This pattern is inferred to reflect an increase in organic carbon burial (e.g., due to elevated marine productivity) concurrently with the oxidation of isotopically light $\mathrm{H}_{2} \mathrm{~S}$, as the result of enhanced vertical advection of nutrient- and sulfide-rich deep waters to the ocean-surface layer. Enhanced upwelling was likely a response to climatic cooling and the reinvigoration of globalocean overturning circulation at the SSB. Coeval decreases in chemical weathering intensity and detrital sediment flux at Shitouzhai are also consistent with climatic cooling. A decline in marine biodiversity was probably associated with the late Smithian thermal maximum (LSTM) rather than with the SSB per se. The SSB thus marked the termination of the extreme hothouse conditions of the GriesbachianSmithian substages of the Early Triassic and is significant as a record of accompanying climatic, environmental, and biotic changes. The ultimate cause of the SSB event is uncertain but
\end{abstract}

may have been related to a reduction in intrusive magmatic activity in the Siberian Traps large igneous province.

\section{Introduction}

The recovery of marine invertebrate faunas and ecosystems after the $\sim 252 \mathrm{Ma}$ end-Permian mass extinction appears to have been the most protracted following any Phanerozoic biocrisis (Erwin, 2001; Bottjer et al., 2008). As with the mass extinction event, many aspects of the Early Triassic recovery remain uncertain, including its timing, pattern, and causes. Species origination rates and biodiversity did not return to pre-extinction levels until the early Middle Triassic, after a protracted process of niche building and increasing ecosystem complexity (Chen and Benton, 2012). The slowness of the recovery process is believed to have resulted, in part, from the effects of sustained or repeated environmental stresses during the Early Triassic (Algeo et al., 2011; Retallack et al., 2011). In particular, the pace of the biotic recovery may have been related to episodic large-scale injection of volcanic $\mathrm{CO}_{2}$ and thermogenic $\mathrm{CH}_{4}$ into the atmosphere, probably from the Siberian Traps large igneous province, and a resulting intensification of ocean anoxia (Retallack and Jahren, 2008; Black et al., 2012).

The extreme environmental conditions (tropical SSTs (sea-surface temperature) $>35^{\circ} \mathrm{C}$ ) of the first $\sim 1.5 \mathrm{Myr}$ of the Early Triassic came to an end at the $\sim 250 \mathrm{Ma}$ SmithianSpathian boundary (SSB), which subdivides the Olenekian stage of the Lower Triassic and which is defined by the first appearance of the conodont Novispathodus pingdingshanen- 
sis at Chaohu, Anhui Province, eastern China (Zhao et al., 2007). The SSB witnessed major changes among marine biotas, including a severe loss of biodiversity among conodonts and ammonoids (Orchard, 2007; Stanley, 2009; Brayard et al., 2009), size reduction (Lilliput effect) among surviving conodont taxa (Chen et al., 2013), and a contraction of the paleolatitudinal range of surviving ammonoid taxa (Galfetti et al., 2007; Brayard et al., 2009). The SSB also marked a major change in global climate, with strong tropical sea-surface cooling (Sun et al., 2012; Romano et al., 2013) and a steepening of the latitudinal temperature gradient (Galfetti et al., 2007). To date, however, the SSB event has received detailed study only in several sections in South China (Galfetti et al., 2007; Liang et al., 2011) and the Salt Range of Pakistan (Hermann et al., 2011). Here, we report the SSB event from a new Lower Triassic section in southern Guizhou Province, South China. We correlate this section with existing SSB sections using a combination of conodont biostratigraphic and carbon isotopic constraints, and we examine changes in marine environmental conditions using a combination of elemental and isotopic proxies, with the goal of better understanding the role of the SSB in the recovery of Early Triassic marine ecosystems.

\section{Smithian-Spathian boundary at the study section}

The study section (GPS: $25^{\circ} 45^{\prime} 9.6^{\prime \prime} \mathrm{N}, 106^{\circ} 6^{\prime} 29.7^{\prime \prime} \mathrm{E}$ ) is located at Shitouzhai village, about $3 \mathrm{~km}$ east of Ziyun county town in southern Guizhou Province, South China (Fig. A1). The geologic and paleontologic background of the Shitouzhai section is described in Appendix A. Its conodont biostratigraphy has been only partly worked out to date due to sporadic fossil occurrence. Ding and Huang (1990) identified a few conodont zones that served to demonstrate an Early to Middle Triassic age for the outcrop. In this study, we detected three key Early Triassic zonal species in the middle to upper Luolou Formation: Novispathodus waageni waageni, which ranges from the late Smithian to early Spathian, and $N v$. pingdingshanensis and Tr. homeri, which are early Spathian in age (Zhao et al., 2007) (Fig. 1). The first occurrence of $N v$. pingdingshanensis is considered to be a marker of the SSB globally (Zhao et al., 2007) (Fig. 2), so its appearance in Bed 14 of the study section provides a firm constraint on the stratigraphic position of the SSB at Shitouzhai. Although the evolutionary progression of $N v$. waageni waageni to $N v$. pingdingshanensis was demonstrated at the betterstudied West Pingdingshan section near Chaohu in Anhui Province (Zhao et al., 2007), this pattern cannot be established for the present study section owing to the scarcity of conodont fossils (Fig. 1).

Carbon isotope chemostratigraphy allows the exact placement of the SSB at Shitouzhai as well as detailed correlation of the study section to biostratigraphically better-studied sections elsewhere. The $\delta^{13} \mathrm{C}_{\text {carb }}$ profile for Shitouzhai shows a

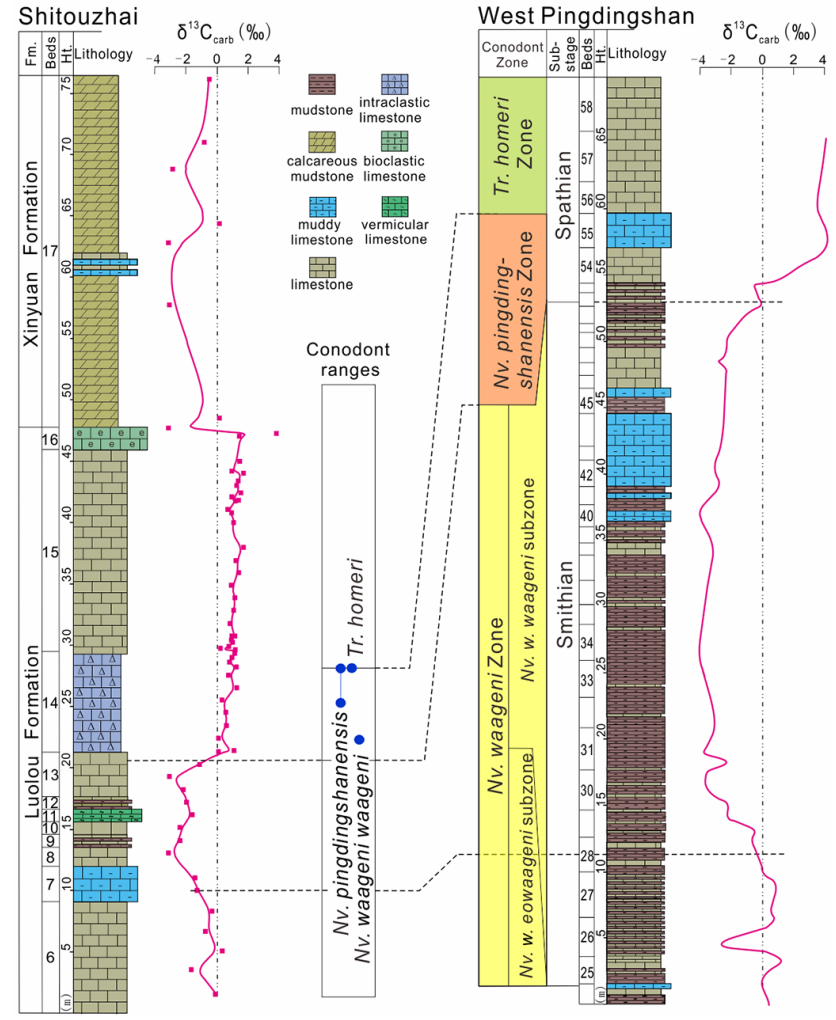

Figure 1. Correlation of the Shitouzhai section in southern Guizhou Province with the West Pingdingshan section in Chaohu, Anhui Province, South China. Sources of West Pingdingshan data: conodont zonation (Zhao et al., 2007) and C-isotope curve (Tong et al., 2007). Correlations between these sections are based primarily on corresponding features in the $\mathrm{C}$-isotope profiles, although limited new conodont data for Shitouzhai (central column; $n=4$ ) provide additional constraints. Fm. and Ht. stand for formation and height, respectively.

pattern of excursions similar to those of other SSB sections in South China and globally (Fig. 2; see Song et al., 2013, for a review), indicating that the carbonate carbon isotope record of the study section was not significantly affected by diagenesis (Appendix B). The mid- to late Smithian is characterized by a major negative excursion (N3 of Song et al., 2013), with a minimum $\delta^{13} \mathrm{C}$ of $-3.2 \%$ at Shitouzhai (compared to ca. -1 to $-4 \%$ globally). The SSB is located in the middle of a rapid positive shift in $\delta^{13} \mathrm{C}$ having a magnitude ranging from +3 to $+7 \%$ globally. At Shitouzhai, this shift amounts to $+3.5 \%$ and the midpoint of the shift is located in the upper part of Bed 13, about $50 \mathrm{~cm}$ below the base of Bed 14, thus narrowly constraining the position of the SSB (Fig. 2). There was limited $\delta^{13} \mathrm{C}_{\text {carb variation during the early }}$ Spathian, with the Shitouzhai study section showing a weak positive drift, whereas most other sections show a weak negative trend within this interval. All sections exhibit a large negative $\delta^{13} \mathrm{C}_{\text {carb }}$ shift in the mid to late Spathian, with minimum values ranging from ca. -1 to $-4 \%$ (Fig. 2). These 


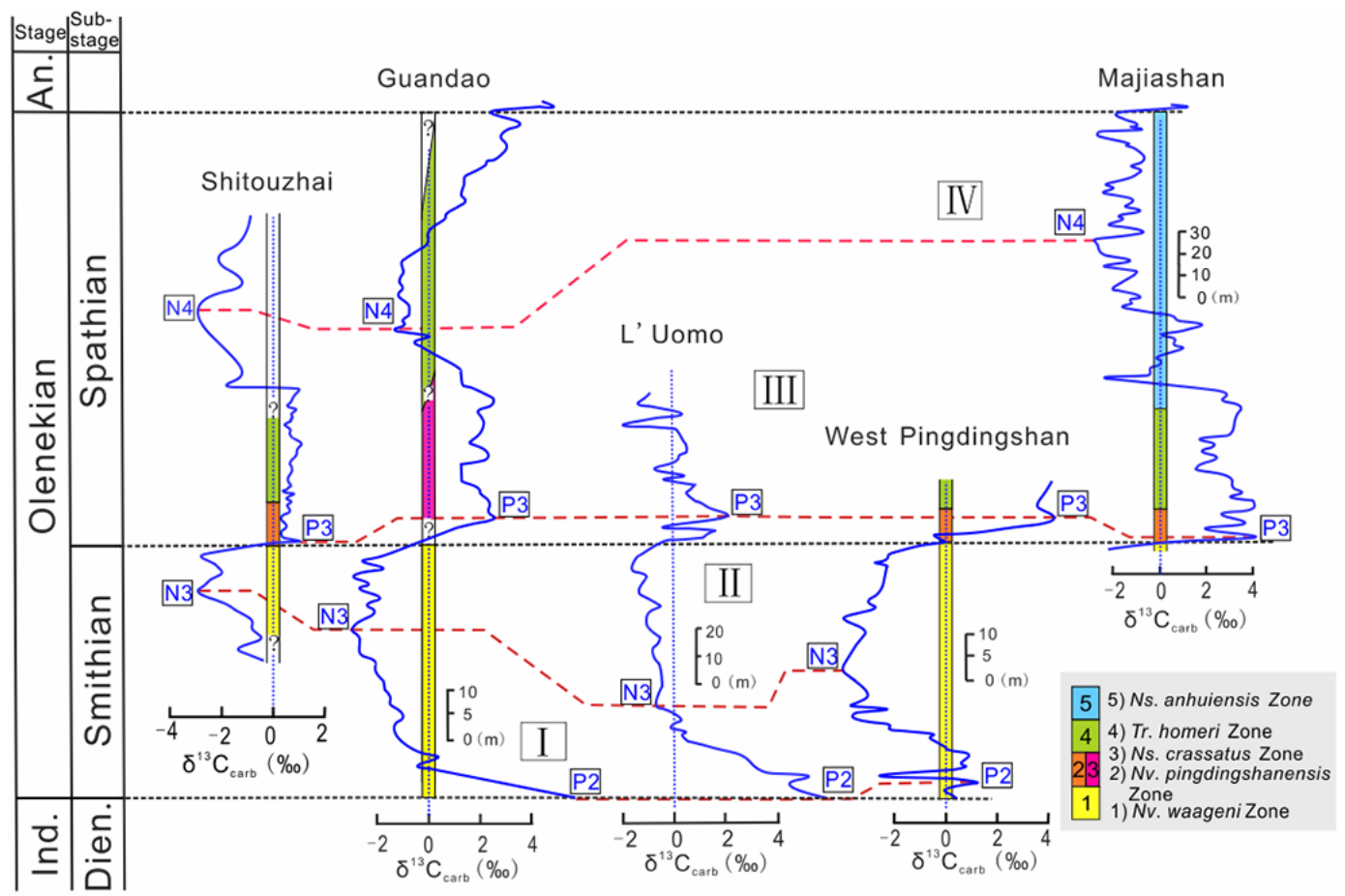

Figure 2. Biostratigraphic and C-isotopic correlations of the Shitouzhai section with other Smithian-Spathian sections. Note that Intervals IIV of $\delta^{13} \mathrm{C}_{\text {carb }}$ profiles are recognizable globally. The standard notation (P2, P3, N3, and N4) for positive and negative C-isotope excursions of the Early Triassic is according to Song et al. (2013). Data for the Guandao, West Pingdingshan, and Majiashan sections are from Tong et al. (2007) and from Horacek et al. (2007) for the L'Uomo section. The different color columns represent corresponding conodont zones from old to young in an ascending order. Question marks represent problematic conodont biozones in need of further study in the Shitouzhai and Guandao sections. An., Ind., and Dien. stand for Anisian, Induan, and Dienerian, respectively.

$\delta^{13} \mathrm{C}_{\mathrm{carb}}$ trends have been well-documented in Lower Triassic sections from around the world (Payne et al., 2004; Tong et al., 2007; Horacek et al., 2007; Song et al., 2013; Grasby et al., 2013).

We have correlated the $\delta^{13} \mathrm{C}_{\text {carb }}$ profile for Shitouzhai with that for the biostratigraphically well-constrained West Pingdingshan section (Tong et al., 2007) (Fig. 1), in which four conodont zones were recognized within the Olenekian Stage. They are the $N v$. w. eowaageni subzone, Nv. w. waageni subzone, $N v$. pingdingshanensis zone, and Triassospathodus homeri zone (Zhao et al., 2007). The $N v$. pingdingshanensis zone is demarcated by the first occurrences of $N v$. pingdingshanensis and Tr. homeri at its base and top, respectively. At Shitouzhai, limited fossil occurrences allow the recognition of three of these conodont zones: the $N v$. w. waageni subzone, the $N v$. pingdingshanensis zone, and the Tr. homeri zone (Fig. 1). The base of the $N v$. pingdingshanensis zone $(=\mathrm{SSB})$ also coincides with a sharp positive $\delta^{13} \mathrm{C}_{\text {carb }}$ excursion that can be correlated globally (Fig. 2).

\section{Methods}

\subsection{Sampling}

Large fresh samples, weighing about 3-4 kg each, were collected from outcrop at the Shitouzhai section. Weathered surfaces and diagenetic veins were trimmed off, and the remaining sample was crushed into small pieces and powdered with a rock mill to $<200$ mesh for geochemical analysis.

\subsection{Carbonate carbon isotope analysis}

About $80-120 \mathrm{mg}$ of powder was placed in a $10 \mathrm{~mL}$ Na glass vial, sealed with a butyl rubber septum, and reacted with $100 \%$ phosphoric acid at $72{ }^{\circ} \mathrm{C}$ after flushing with helium. The evolved $\mathrm{CO}_{2}$ gas was analyzed for $\delta^{13} \mathrm{C}$ and $\delta^{18} \mathrm{O}$ using a MAT 253 mass spectrometer in the State Key Laboratory of Geological Processes and Mineral Resources at the China University of Geosciences, Wuhan. All isotopic data are reported as per mille variation $(\% o)$ relative to Vienna Pee Dee belemnite (V-PDB) standard. The analytical precision is better than $\pm 0.1 \%$ o for $\delta^{13} \mathrm{C}$ and $\pm 0.2 \%$ or for $\delta^{18} \mathrm{O}$ based on duplicate analyses of the national reference standard GBW$04416\left(\delta^{13} \mathrm{C}=1.61 \% o\right)$. 


\subsection{CAS extraction and sulfur isotope analysis}

Carbonate-associated sulfate (CAS) concentrations and isotopes $\left(\delta^{34} \mathrm{~S}_{\mathrm{CAS}}\right)$ were determined for samples containing $>30 \mathrm{wt} \% \mathrm{CaCO}_{3}$. These samples were powdered, leached of soluble sulfates in a $10 \% \mathrm{NaCl}$ solution, rinsed three times in deionized water, and dissolved in $3 \mathrm{~N} \mathrm{HCl}$. The acidified samples were filtered, and an excess of $1 \mathrm{M} \mathrm{BaCl}_{2}$ was added to the filtrate to precipitate $\mathrm{BaSO}_{4}$. The $\mathrm{BaSO}_{4}$ precipitate was rinsed, filtered, dried, and then combined with an excess of $\mathrm{V}_{2} \mathrm{O}_{5}$ and analyzed for its $\mathrm{S}$-isotope composition in the State Key Laboratory of Biogeology and Environmental Geology at the China University of Geosciences, Wuhan. Sulfur isotope compositions are expressed in standard $\delta$-notation as per mille (\%o) variation with respect to V-CDT (ViennaCañon Diablo Troilite), with an analytical error of $\sim 0.1 \%$ o calculated from replicate analyses of samples and the laboratory standards NBS (National Bureau of Standards) 127 (21.1\%o), IAEA (International Atomic Energy Agency) SO$5(0.49 \%$ ) and IAEA SO-6 (-34.05\%). CAS concentrations were calculated from the mass of recovered $\mathrm{BaSO}_{4}$.

\subsection{Elemental analysis}

The measurement of major and trace element concentrations was carried out in the State Key Laboratory of Geological Processes and Mineral Resources at the China University of Geosciences, Wuhan, following the procedure of national standards (GB/T 14506-2010) and Liu et al. (2008). A Hitachi atomic absorption spectrophotometer (180-70) and an ultraviolet-visible spectrophotometer (UV-754) were utilized in major element analysis. An Aglient 7500a ICPMS (Inductively coupled plasma mass spectrometer) was used to analyze trace element concentrations with an average analytical uncertainty of better than $2 \%$ (RSD, relative standard deviation). Results were calibrated using the laboratory standards AGV-2, BHVO-2, and BCR-2. Rare earth element (REE) concentrations were normalized (N) to the average upper crustal composition of McLennan (2001). In order to calculate enrichment ratios, lanthanum $(\mathrm{La})$, samarium $(\mathrm{Sm})$, and ytterbium $(\mathrm{Yb})$ were used as proxies for the light (LREEs), middle (MREEs) and heavy rare earth elements (HREEs), respectively. The europium anomaly $\left(\mathrm{Eu} / \mathrm{Eu}^{*}\right)$ was calculated as $2 \mathrm{Eu}_{\mathrm{N}} /\left(\mathrm{Sm}_{\mathrm{N}}+\mathrm{Gd}_{\mathrm{N}}\right)$ and the cerium anomaly $\left(\mathrm{Ce} / \mathrm{Ce}^{*}\right)$ was calculated as $3 \mathrm{Ce}_{\mathrm{N}} /\left(2 \mathrm{La}_{\mathrm{N}}+\mathrm{Nd}_{\mathrm{N}}\right)$. The chemical index of alteration (CIA) was calculated as $\mathrm{Al}_{2} \mathrm{O}_{3} /\left(\mathrm{Al}_{2} \mathrm{O}_{3}+\mathrm{K}_{2} \mathrm{O}+\mathrm{Na}_{2} \mathrm{O}\right)$. This is a modified form of the original CIA equation (Nesbitt and Young, 1982) that eliminates $\mathrm{CaO}$ from the denominator, which is superior for use in carbonate-rich sedimentary successions. The $\mathrm{Th} / \mathrm{Th}^{*}$ ratio, where $\mathrm{Th}^{*}$ represents the average thorium concentration of the upper crust (10.7 ppm; Bau, 1996), can be used to estimate the fraction of clay minerals in carbonate units.

\subsection{Age model and sediment flux calculations}

An age model was developed in order to calculate sediment fluxes for the Shitouzhai section. Age constraints were provided by chemical abrasion-thermal ionization mass spectrometry (CA-TIMS) studies of U-Pb in zircons, from which the dates of the Induan-Olenekian and SmithianSpathian boundaries were estimated at $\sim 251.25 \mathrm{Ma}$ and $\sim 250.55 \mathrm{Ma}$, respectively (Ovtcharova et al., 2006), and that of the Olenekian-Anisian boundary was estimated at $\sim 247.3 \mathrm{Ma}$ (Lehrmann et al., 2006). These dates yield durations for the Smithian and Spathian substages of $\sim 0.7$ and $\sim 3.25 \mathrm{Myr}$, respectively. The age of each sample in the Shitouzhai section was estimated through linear interpolation between these dated horizons (Fig. 3a). This age model yielded linear sedimentation rates (LSRs) of 43 and $21 \mathrm{~m} \mathrm{Myr}^{-1}$ for the Smithian and Spathian portions of the study section, respectively. Sediment bulk accumulation rates (BAR) were calculated as

$\mathrm{BAR}=\mathrm{LSR} \times \mathrm{BSD} / 10$,

where an average value of $2.5 \mathrm{~g} \mathrm{~cm}^{-3}$ was assumed for bulk sediment density (BSD) and 10 is a coefficient to convert units of $\mathrm{m} \mathrm{Myr}^{-1} \times \mathrm{g} \mathrm{cm}^{-3}$ to $\mathrm{g} \mathrm{cm}^{-3} \mathrm{kyr}^{-1}$. The mass accumulation rates of carbonate and clay $\left(\mathrm{MAR}_{\text {carb }}\right.$ and $\mathrm{MAR}_{\text {clay }}$, respectively) in the study section were calculated as

$\mathrm{MAR}_{\text {carb }}=\mathrm{BAR} \times \% \mathrm{TIC} / 12.0$,
$\mathrm{MAR}_{\text {clay }}=\mathrm{BAR} \times \% \mathrm{Al} / 8.04$,

where \% TIC and \% $\mathrm{Al}$ are the concentrations of total inorganic carbon and aluminum in each study sample, respectively, and the coefficients 12.0 and 8.04 are the concentrations in percent of TIC in pure calcium carbonate and $\mathrm{Al}$ in average upper continental crust, respectively (McLennan, 2001).

\section{Results}

\subsection{Carbonate carbon isotopic excursions}

$\delta^{13} \mathrm{C}_{\text {carb }}$ values range from -3.2 to $1.8 \%$ o through the SSB interval in the study section, with a mean value of about $0.01 \%$ (Fig. 4; Appendix C). A sharp positive shift in $\delta^{13} \mathrm{C}_{\text {carb }}$, from -3.1 to $1.0 \%$, occurs across the SSB. The large excursions in the $\delta^{13} \mathrm{C}_{\text {carb }}$ profile for the whole Shitouzhai section mirror excursions seen in Smithian-Spathian sections globally, providing a strong basis for interregional correlations (Fig. 2). These excursions allow the recognition of four carbon isotope intervals, with Interval I characterized by $\delta^{13} \mathrm{C}$ decreasing to a minimum at N3 (late Smithian), Interval II by $\delta^{13} \mathrm{C}$ increasing to a maximum at $\mathrm{P} 3$ (the SSB), Interval III by $\delta^{13} \mathrm{C}$ decreasing to a minimum at $\mathrm{N} 4$ (midSpathian), and Interval IV by $\delta^{13} \mathrm{C}$ increasing to a maximum 

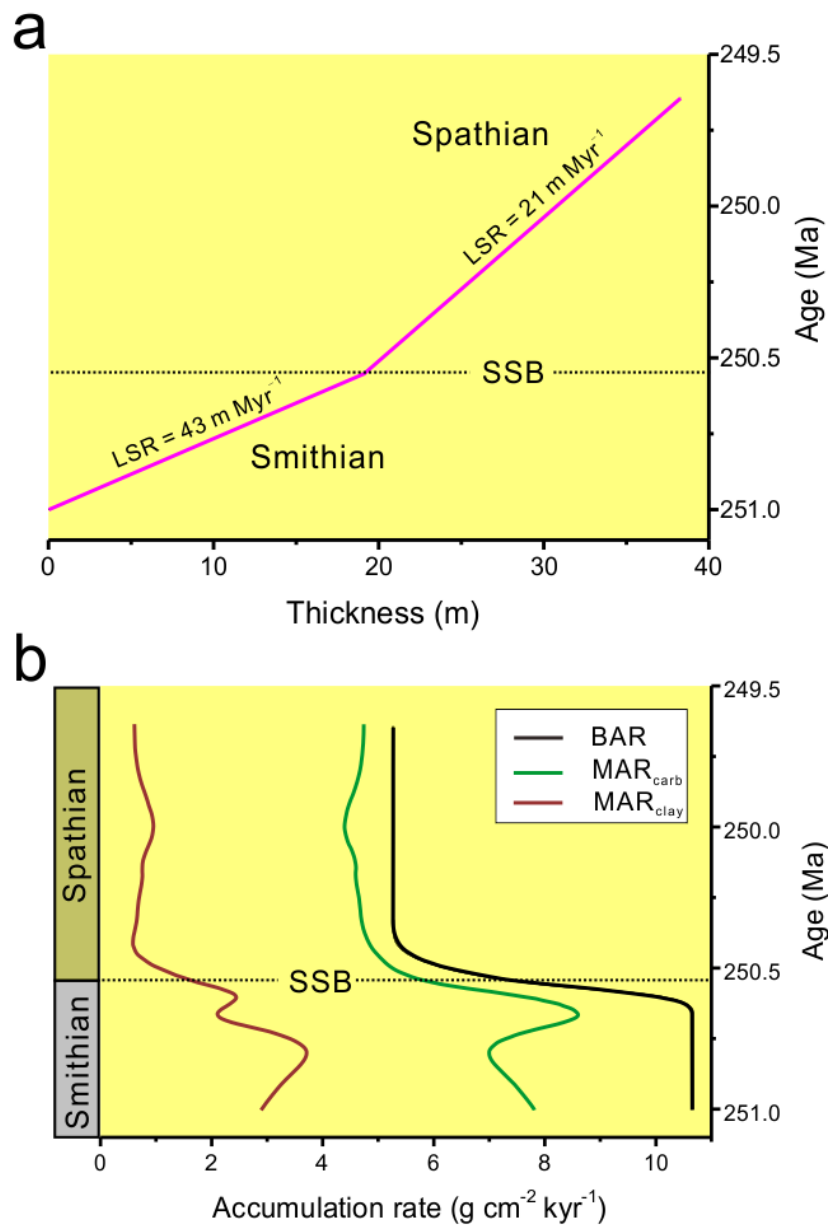

Figure 3. (a) Age-depth model and (b) sediment accumulation rates around the SSB in the Shitouzhai section. BAR, MAR ${ }_{\text {carb }}$, and $\mathrm{MAR}_{\text {clay }}$ stand for bulk accumulation rate, carbonate mass accumulation rate, and clay mass accumulation rate, respectively. SSB stands for Smithian-Spathian boundary.

at P4 (earliest Anisian) (Fig. 2; cf. Song et al., 2013). At Shitouzhai, Interval I encompasses Beds 6-7, Interval II Beds 8-13, Interval III Beds 14-15, and Interval IV Beds 16-17.

\subsection{CAS-sulfur isotopes}

$\delta^{34} \mathrm{~S}_{\mathrm{CAS}}$ values range from 23.6 to $37.9 \%$ with a mean value of $29.7 \%$. The $\delta^{34} \mathrm{~S}_{\mathrm{CAS}}$ profile exhibits a slight negative trend upsection, although interrupted by several negative and positive excursions (Fig. 4; Appendix C). The $\delta^{34} \mathrm{~S}_{\mathrm{CAS}}$ profile exhibits a significant negative correlation with the $\delta^{13} \mathrm{C}_{\text {carb }}$ profile $(r=-0.38)$. This covariation is particularly pronounced around the SSB, where a $\sim 4 \%$ o positive shift in the $\delta^{13} \mathrm{C}_{\text {carb }}$ profile is mirrored by a $10-15 \%$ negative shift in the $\delta^{34} \mathrm{~S}_{\text {CAS }}$ profile (Fig. 4).

\subsection{Trace element concentrations}

Total REE concentrations ( $\sum \mathrm{REE}$ ) values range from 17 to $46 \mathrm{ppm}$, with higher mean values below the SSB (43 ppm) than above it (23 ppm) (Fig. 4; Appendix C). Th/ Th* ratios exhibit a similar pattern to $\sum$ REE, with higher mean values below the SSB (0.27) than above it (0.13). Y / Ho ratios range from 30.7 to 37.2 with a mean value of $\sim 34$. Eu/Eu* ratios range from 0.95 to 1.20 and are mainly close to $0.9-1.0$ throughout the section. $\mathrm{Sm}_{\mathrm{N}} / \mathrm{Yb}_{\mathrm{N}}$ ratios fluctuate between 0.98 and 1.42 , with relatively higher and stable values below the SSB and more variable values above the SSB (Fig. 4).

$\mathrm{Th} / \mathrm{U}$ ratios range from 0.34 to 1.56 , with values mostly $>1.0$ below the SSB and mostly < 1.0 above it (Fig. 4; Appendix $\mathrm{C}$ ). $\mathrm{Ce} / \mathrm{Ce}^{*}$ ratios range from 0.73 to 0.88 , with higher values below the SSB than above it. The chemical index of alteration (CIA) values range from 0.69 to 0.78 but are consistently higher below the SSB $(>0.75)$ than above it $(<0.73) . \mathrm{Mn} / \mathrm{Th}$ ratios are uniformly low $(<300)$ below the SSB but more variable and generally higher (to $\sim 1900$ ) above the SSB (Fig. 4). Sr concentrations range from 508 to $2160 \mathrm{ppm}$, and $\mathrm{Mn}$ concentrations range from 230 to $3776 \mathrm{ppm}$ (Appendix C). Mn / Sr values are uniformly < 1 below the SSB and range from 0.24 to 3.8 with a median value of 2.1 above the SSB (Fig. B1). All of these elemental proxies exhibit a significant excursion at or close to the SSB (Fig. 4).

\subsection{Sediment fluxes}

Bulk accumulation rates (BAR) are higher in the Smithian $\left(\sim 11 \mathrm{~g} \mathrm{~cm}^{-2} \mathrm{kyr}^{-1}\right)$ than in the Spathian $\left(\sim 5 \mathrm{~g} \mathrm{~cm}^{-2} \mathrm{kyr}^{-1}\right)$ (Fig. 3b). Carbonate mass accumulation rates $\left(\mathrm{MAR}_{\mathrm{carb}}\right)$ fluctuated in the range of $7-9 \mathrm{~g} \mathrm{~cm}^{-2} \mathrm{kyr}^{-1}$ below the SSB and declined to $4-5 \mathrm{~g} \mathrm{~cm}^{-2} \mathrm{kyr}^{-1}$ above the SSB. Clay mass accumulation rates $\left(\mathrm{MAR}_{\text {clay }}\right)$ fluctuated in the range of $2-4 \mathrm{~g} \mathrm{~cm}^{-2} \mathrm{kyr}^{-1}$ below the SSB and declined to $<1 \mathrm{~g} \mathrm{~cm}^{-2} \mathrm{kyr}^{-1}$ above the SSB. On a fine scale below the $\mathrm{SSB}, \mathrm{MAR}_{\text {carb }}$, and $\mathrm{MAR}_{\text {clay }}$ varied inversely because carbonates and clays are the two main components of the study section and, hence, produced dilutive effects of one component by the other.

\section{Discussion}

\subsection{Weathering rate changes}

Studies of both modern and ancient carbonates show that a primary seawater signature is characterized by low $\sum$ REE and relative HREE enrichment (Webb et al., 2009). However, carbonate sediments containing even a minor amount of clay minerals tend to acquire a terrigenous REE signal characterized by high $\sum$ REE and strong LREE or MREE enrichment (Sholkovitz and Shen, 1995; Bright et al., 2009). At Shitouzhai, $\sum$ REE exhibits a strong positive correlation with 


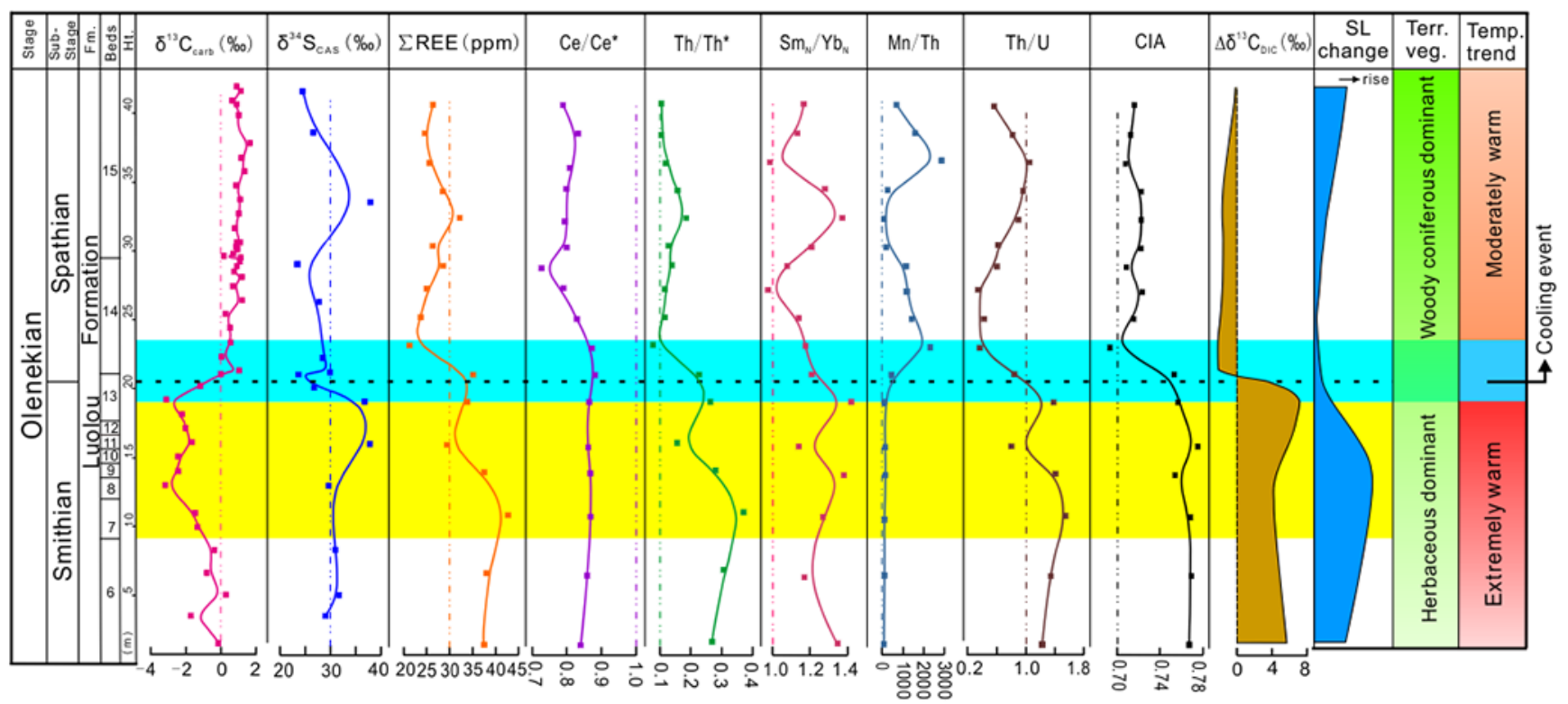

Figure 4. Chemostratigraphic profiles and environmental changes during the Smithian-Spathian transition. The $\delta^{13} \mathrm{C}_{\mathrm{carb}}$ and $\delta^{34} \mathrm{~S}_{\mathrm{CAS}}$ profiles and trace element ratios at Shitouzhai show coupling with vertical gradients in marine carbonate $\delta^{13} \mathrm{C}\left(\Delta \delta^{13} \mathrm{C}_{\mathrm{DIC}}\right)$, global sea-level elevation, and terrestrial vegetation changes during the Olenekian. $\Delta \delta^{13} \mathrm{C}_{\mathrm{DIC}}$ is from Song et al. (2013), sea-level variation from Yin and Tong (1996), and terrestrial vegetation from Saito et al. (2013). REE, CIA, SL, Terr. veg., and Temp. stand for rare earth elements, chemical index of alteration, sea level, terrestrial vegetation, and temperature, respectively.

Th $(r=+0.97$; Fig. 5a), indicating that REEs came from the detrital clay fraction not the hydrogenous (seawater) fraction (Zhao et al., 2013). Moreover, the clay fraction (as estimated from $\mathrm{Th} / \mathrm{Th}^{*}$ ) is substantial, ranging from $\sim 10$ to $30 \%$ of the total sample, which reflects the argillaceous/muddy character of carbonates in the study section.

All samples at Shitouzhai yield Y/Ho ratios of $\sim 30-35$ (Appendix C), which are closer to terrestrial values $(\sim 25$ 30) than to seawater values (44-74) (Bau, 1996; Webb et al., 2009). $\sum$ REE also exhibits a modest negative correlation with Y/Ho $(r=-0.65$; Fig. $5 b)$. Thus, a large component of the REEs in the study section is terrestrially derived, probably through release from clay minerals during diagenesis. Nearly all $\mathrm{Eu} / \mathrm{Eu}^{*}$ ratios are in the range of 0.9-1.0 (Appendix C), which are typical of crustal rocks and are consistent with the uptake of REEs from clay minerals (McLennan, 2001). MREE enrichment is rather strong (most samples yield $\mathrm{Sm}_{\mathrm{N}} / \mathrm{Yb}_{\mathrm{N}}>1.0$; Fig. 4), suggesting the presence of phosphate in the sediment or the influence of pore waters previously in contact with phosphate (Kidder and EddyDilek, 1994; Bright et al., 2009).

All of the detrital proxies from the study section provide evidence of a major decrease in weathering intensity at the SSB. The age-depth model for the study section (Fig. 3a) shows that the SSB is characterized by a large decline in linear sedimentation rates (LSRs) from 43 to $21 \mathrm{~m} \mathrm{Myr}^{-1}$ and a proportional decrease in bulk accumulation rates (BAR) from 10.7 to $5.3 \mathrm{~g} \mathrm{~cm}^{-2} \mathrm{kyr}^{-1}$ (Fig. 3b). The mass accumulation rates (MAR) of both clays and carbonate also declined across the SSB, although the decline was larger for clays $(\sim 80$ $90 \%$ ) than for carbonate ( $30-40 \%$; Fig. 3b). These proportional differences reflect the greater concentration of clays in Smithian beds relative to Spathian beds. The sharp decline in $\sum$ REE concentrations near the SSB (Fig. 4) is also evidence of a decrease in clay-mineral content upsection. The CIA has been widely used as a proxy for chemical weathering intensity in sediment source regions (Nesbitt and Young, 1982; Goldberg and Humayun, 2010). The abrupt decline in CIA values at Shitouzhai, from $\sim 0.76-0.78$ to $\sim 0.70-0.72$ (Fig. 4), probably indicates a major decrease in chemical weathering intensity at the SSB. This interpretation is supported by strong correlations of CIA with many detrital proxies, including $\mathrm{Al}(r=+0.87)$, $\Sigma$ REE $(r=+0.81)$, Th $/ \mathrm{Th}^{*}$ $(r=+0.81)$, and LSR $(r=+0.93)$. Although changes in CIA potentially can be due to changes in sediment provenance (e.g., Price and Velbel, 2003), the weak correlation of $\mathrm{CIA}$ to $\mathrm{Eu} / \mathrm{Eu}^{*}(r=-0.21)$ argues against this interpretation.

All detrital proxies for the Shitouzhai section are thus consistent in documenting a major decrease in both chemical and physical weathering intensity at the SSB (Fig. 6). These changes are reflected in lower CIA values, greatly reduced clay-mineral production, and more limited transport of siliciclastics to shallow marine systems. Lower bulk sediment fluxes merely reflect a return to more typical longterm values, however, as the Griesbachian-Smithian inter- 

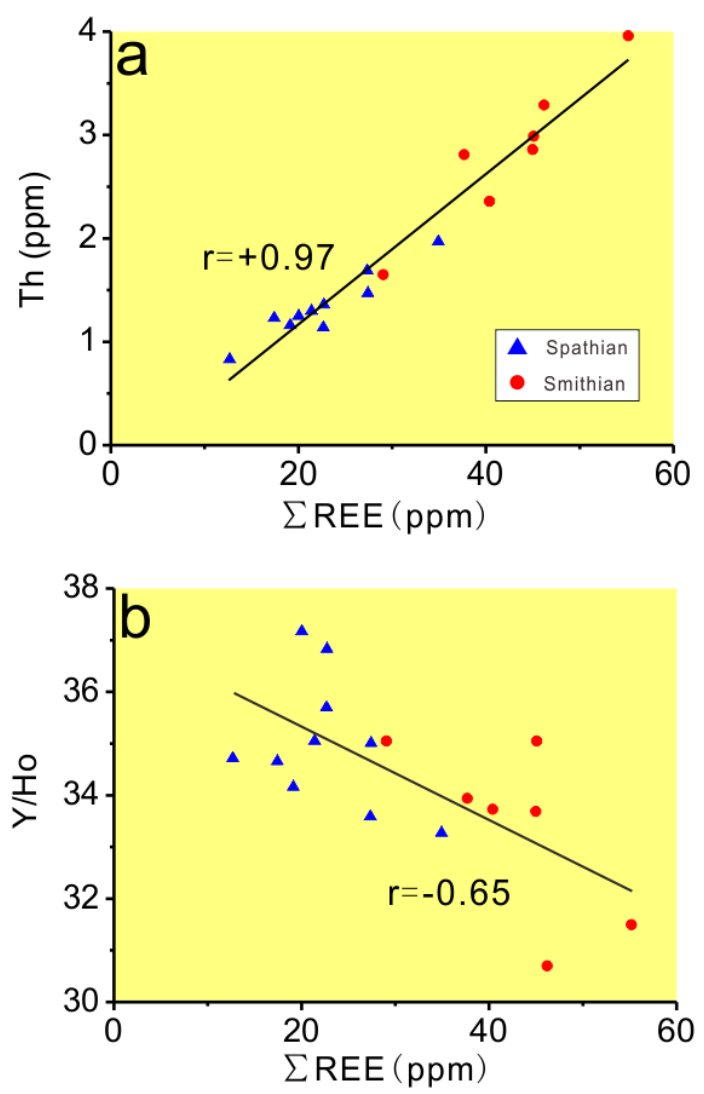

Figure 5. Crossplots of (a) $\sum$ REE vs. Th and (b) $\sum$ REE vs. Y / Ho. Strong positive covariation demonstrates derivation of REEs primarily from the terrigenous siliciclastic (clay-mineral) fraction of the sediment.

val of the Early Triassic was characterized by exceptionally high sediment fluxes and chemical weathering rates (Algeo and Twitchett, 2010). These weathering-related changes at the SSB are likely to have been due to a sharp, $\sim 5^{\circ} \mathrm{C}$ temperature decrease in the tropics (Sun et al., 2012; Romano et al., 2013). Even the decline in carbonate flux may have been a consequence of reduced riverine inputs of $\mathrm{Ca}^{2+}$ and $\mathrm{CO}_{3}^{2-}$ ions to marine systems, although other factors such as climatic cooling or changes in oceanic thermohaline circulation may have influenced marine carbonate production.

\subsection{Oceanic redox variation}

The concentrations of redox-sensitive trace elements (e.g., Mo, U, and V) are low (i.e., close to detrital background values) in all samples from the study section, although there is a slight increase around the SSB, especially on a Thnormalized basis (Appendix C). However, there is an even larger increase in $\mathrm{Mn} / \mathrm{Th}$ at this level (Fig. 4). Under reducing conditions, $\mathrm{Mn}^{2+}$ is highly soluble and does not accumulate in substantial amounts in marine sediments. However, suboxic to oxic conditions commonly result in Mn en-
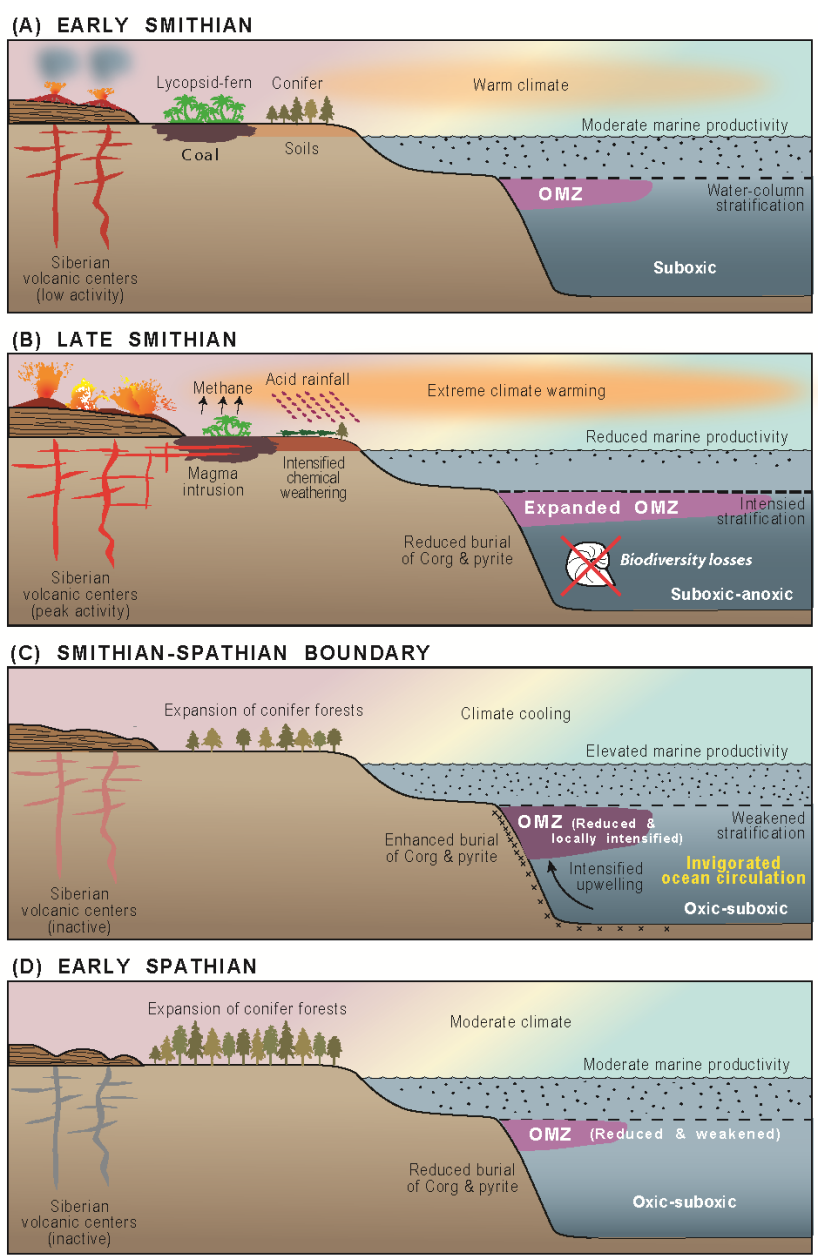

Figure 6. Evolution of terrestrial and marine environments during the late Early Triassic: (a) early Smithian, (b) late Smithian thermal maximum (LSTM), (c) Smithian-Spathian boundary, and (d) early Spathian. This model integrates changes in subaerial weathering rates and oceanic productivity and redox conditions documented in this study with data regarding paleoclimate variation, terrestrial floral assemblages, and marine biodiversity patterns from other sources (cited in text). We infer that the modeled environmental changes were ultimately due to variation in the eruption rate of the Siberian Traps, although this has not been proven to date. See text for further discussion.

richment through the accumulation of $\mathrm{Mn}$ (II) in carbonates or Mn(III) in oxyhydroxides (Okita et al., 1988). Strong Mn enrichment is thus common on the margins of reducing deep water masses (Landing and Bruland, 1987). Mn enrichment in carbonates is accepted as a good indicator of suboxic conditions (Rue et al., 1997; Pakhomova et al., 2007). At Shitouzhai, the $\mathrm{Mn} / \mathrm{Th}$ profile suggests dominantly anoxic conditions below the SSB $(0-18 \mathrm{~m})$ and suboxic conditions above it (20-37 m), although with a brief interlude of more reducing conditions during the early Spathian (28-32 m; Fig. 4). 
Cerium (Ce) is the only REE that is affected by oxidationreduction processes in the Earth-surface environment. Under reducing conditions, $\mathrm{Ce}^{3+}$ has the same valence as other REEs and, therefore, is not fractionated relative to them, yielding $\mathrm{Ce} / \mathrm{Ce}^{*}$ ratios of $\sim 1.0$ (German and Elderfield, 1990). Under oxidizing conditions, $\mathrm{Ce}^{4+}$ is preferentially removed from solution, yielding local sedimentary deposits with $\mathrm{Ce} / \mathrm{Ce}^{*}>1.0$, whereas the $\mathrm{Ce} / \mathrm{Ce}^{*}$ ratio of seawater and of any hydrogenous deposits incorporating REEs from seawater is < 1.0 (e.g., 0.3-0.4 in the modern ocean). Thus, Ce is potentially a good proxy for marine paleoredox conditions, provided that a hydrogenous signal can be measured (Wright et al., 1987). Terrigenous influence (e.g., addition of REEs from clay minerals) will generally cause $\mathrm{Ce} / \mathrm{Ce} *$ ratios to converge on 1.0, which is by definition the value for average upper crustal rocks. In the study section, $\mathrm{Ce} / \mathrm{Ce} *$ ratios vary from 0.79 to 0.88 (Fig. 4). These moderately high values are nominally indicative of suboxic conditions. However, the $\mathrm{Ce} / \mathrm{Ce}^{*}$ ratio was probably heavily influenced by REEs from the clay fraction of the sediment, making the $\mathrm{Ce} / \mathrm{Ce}^{*}$ ratio of any hydrogenous contribution uncertain.

$\mathrm{Th} / \mathrm{U}$ ratios are useful for paleoredox analysis, owing to the redox-dependent behavior of U. Under oxidizing conditions, U(VI) tends to form stable carbonate complexes in seawater (Langmuir, 1978; Algeo and Maynard, 2004). Under reducing conditions, $\mathrm{U}(\mathrm{IV})$ is readily removed to the sediment. Th, however, is not subject to the influence of redox condition, resulting in higher $\mathrm{Th} / \mathrm{U}$ ratios under reducing conditions as aqueous $U$ is lost (Wignall and Myers, 1988). In the study section, a distinct decrease in the $\mathrm{Th} / \mathrm{U}$ ratio at the SSB indicates a shift toward more oxygenated conditions, which was sustained into the early Spathian (Fig. 4). These results are consistent with dominantly oxic to suboxic conditions in the study area following the SSB (Fig. 6).

\subsection{Significance of C-S isotopic variation at the SSB}

Seawater sulfate $\delta^{34} \mathrm{~S}$ rose sharply from $\sim+15 \%$ in the late Permian to $>+30 \%$ in the Middle Triassic (Claypool et al., 1980; Kampschulte and Strauss, 2004), although the pattern of increase during the Early Triassic has only recently begun to be worked out (Song et al., 2014). The present study provides the most comprehensive analysis of $\delta^{34} \mathrm{~S}_{\mathrm{CAS}}$ variation at the SSB of any study to date. The Shitouzhai section exhibits a distinct, $\sim 10-15 \%$ o negative shift in $\delta^{34} \mathrm{~S}_{\mathrm{CAS}}$ that is paired with a $\sim 4 \%$ positive shift in $\delta^{13} \mathrm{C}_{\text {carb }}$ (Fig. 4). Both shifts are limited to a narrow interval around the SSB, probably representing no more than $\sim 75-150 \mathrm{kyr}$ based on average sedimentation rates for the study section (Fig. 3a). These two features (i.e., negative covariation and a short event interval) impose significant constraints on the underlying causes of the isotopic shifts. Most of the Early Triassic is characterized by positive $\delta^{13} \mathrm{C}_{\mathrm{carb}}-\delta^{34} \mathrm{~S}_{\mathrm{CAS}}$ covariation, a pattern that is consistent with control by sediment burial fluxes, i.e., co-burial of organic carbon and pyrite, linked to variations in marine productivity and/or redox conditions (Luo et al., 2010; Song et al., 2014). In contrast, negative $\delta^{13} \mathrm{C}_{\mathrm{carb}}-\delta^{34} \mathrm{~S}_{\mathrm{CAS}}$ covariation during a short-term event at the SSB is indicative of oceanographic controls. Specifically, we hypothesize that cooling-driven reinvigoration of oceanic overturning circulation led to stronger upwelling, mixing nutrient- and sulfide-rich deep waters upward into the oceansurface layer and causing both enhanced marine productivity (hence higher $\delta^{13} \mathrm{C}_{\text {DIC }}$ ) and oxidation of advected $\mathrm{H}_{2} \mathrm{~S}$ (hence lower $\delta^{34} \mathrm{~S}_{\text {sulfate }}$ ) (Fig. 6). Such an oceanographic process was inherently transient, lasting only until the nutrients and sulfide that had accumulated in the deep ocean during the Griesbachian-Smithian interval of intense oceanic stratification (Song et al., 2013) became depleted. The same process was inferred for the latest Spathian by Song et al. (2014), an interval also characterized by short-term negative $\delta^{13} \mathrm{C}_{\text {carb }}-$ $\delta^{34} \mathrm{~S}_{\mathrm{CAS}}$ covariation (Song et al., 2014, their figure 6) and linked to global climatic cooling (Sun et al., 2012). These considerations underscore the fundamental significance of the SSB, which represents the termination of the Early Triassic hyper-greenhouse climate and the reinvigoration of global-ocean overturning circulation (Fig. 6).

\subsection{Causes and consequences of the SSB event}

Oceanographic changes at the SSB had a major effect on contemporaneous marine biotas. Several invertebrate clades, including ammonoids, conodonts, and foraminifera, appear to have suffered severe losses of biodiversity at this time (Orchard, 2007; Stanley, 2009; Song et al., 2011). Ammonoids diversified greatly during the Griesbachian to Smithian but underwent a major evolutionary turnover at the SSB, followed by a stepwise increase in biodiversity in the early to middle Spathian (Brayard et al., 2009). Conodonts show a similar pattern, with a rapid radiation in the early to middle Smithian terminated by a severe extinction at the SSB, followed by a second radiation in the early to middle Spathian (Orchard, 2007). Changes in biodiversity were mirrored by changes in body size. Chen et al. (2013) documented a brief but significant size reduction among conodonts, coinciding with the late Smithian thermal maximum (Sun et al., 2012), based on bulk sample analysis from an outcrop section in Guizhou Province, southwestern China. Conodonts remained diminutive during the SSB transition and the earliest Spathian and then underwent a stepwise size increase during the early to middle Spathian (Chen et al., 2013).

Although literature surveys show that marine clades such as conodonts, ammonoids, and foraminifera experienced a sharp decline in diversity at the SSB (Orchard, 2007; Stanley, 2009; Song et al., 2011), this pattern may be biased by data binning effects. In fact, an examination of the stratigraphic distribution of these marine clades in actual geological sections suggests that diversity losses occurred slightly prior to the SSB (Zhao et al., 2007; Song et al., 2011; Zakharov and Popov, 2014) and were probably associated with 
the late Smithian thermal maximum (Sun et al., 2012; Romano et al., 2013; Fig. 6) rather than the Smithian-Spathian boundary itself. The affected marine clades also did not recover immediately when climatic and environmental conditions ameliorated abruptly at the SSB but, rather, underwent a stepwise recovery during the early to middle Spathian (Orchard, 2007; Stanley, 2009; Brayard et al., 2009).

The SSB was characterized by a major change in terrestrial flora. Lycopsid-dominated assemblages were replaced by conifer-dominated or mixed lycopsid-conifer vegetation, as indicated by palynological data from Pakistan (Hermann et al., 2011), Norway (Galfetti et al., 2007; Hochuli and Vigran, 2010), and central Europe (Kurscher and Herngreen, 2010). A similar floral change was reported from the SpathianAnisian boundary in Hungary (Looy et al., 1999), suggesting some variation in the timing of terrestrial floral recovery in different regions of the world. Macrofloral fossil evidence indicates a more volatile record of vegetation change, with multiple short-term expansions of lycopsids from tropical regions temporarily displacing conifers during the Olenekian (Retallack et al., 2011; Hochuli et al., 2010; Looy et al., 2001). These inferences are supported by biomarker and biogeochemical studies. Saito et al. (2013) reported that sediments of Griesbachian to Smithian age yield carbon/nitrogen $(\mathrm{C} / \mathrm{N})$ ratios $<10$ and contain abundant retene, simonellite, and dehydroabietan, which are interpreted to have been sourced from lycopsids and/or bryophytes. After the SSB, sediments yield $\mathrm{C} / \mathrm{N}$ ratios $>10$ and exhibit a large increase in pimanthrene abundance, suggesting the dominance of terrestrial floras by conifers. As a result, a highly diverse coniferous flora became widely reestablished around the SSB, replacing the lycopsid- and fern-dominated disaster-type vegetation that had dominated the Griesbachian to Smithian interval (Saito et al., 2013; Fig. 6).

The SSB was also characterized by major environmental changes. Strong climatic cooling has been inferred from both faunal (Galfetti et al., 2007) and oxygen-isotope evidence (Sun et al., 2012; Romano et al., 2013). Changes in oceanic circulation appear to have occurred at the same time. Saito et al. (2013) interpreted an increase in extended tricyclic terpane ratios (ETR) around the SSB as being due to a shift from limited to vigorous overturning circulation (Fig. 6). These climatic and oceanographic changes were probably linked: an increase in the intensity of global meridional circulation would have been a natural consequence of climatic cooling (e.g., Rind, 1998), leading to more vigorous deepwater formation in high-latitude regions (Kiehl and Shields, 2005).

The environmental and climatic changes documented at Shitouzhai reinforce observations made in other SSB sections globally and, thus, serve to demonstrate that these changes were widespread and characteristic of the SSB. We propose that all of the changes in our model (Fig. 6) were due to a cooling event that commenced following the LSTM and that continued strongly across the SSB. In particular, we infer that cooling led to the reinvigoration of global-ocean overturning circulation. It should be noted that we are not envisioning complete ocean stagnation during the preceding Griesbachian-Smithian interval, which is unlikely, based on physical oceanographic principles (e.g., Kiehl and Shields, 2005), but, rather, a strong slowing of overturning circulation that led to a buildup of nutrients in the deep ocean (Fig. 6). The reinvigoration of global-ocean circulation at the SSB flushed this buildup of nutrients back into the ocean-surface layer, triggering a transient increase in marine productivity and an expansion of thermoclinal anoxia that lasted until this deepwater nutrient source was depleted. The brevity of the SSB anoxic event at Shitouzhai, which lasted 75-150 kyr, is consistent with such a mechanism. This mechanism also accounts for the abrupt, large positive shift in $\delta^{13} \mathrm{C}_{\text {carb }}$ at the $\mathrm{SSB}$, which was due to a productivity-related increase in organic carbon burial rates (Fig. 6).

The ultimate cause of the SSB event is uncertain. Given that the onset of the Permian-Triassic boundary crisis has been firmly linked to the initiation of the main eruptive phase of the Siberian Traps large igneous province (STLIP) (Renne et al., 1995; Kamo et al., 2003) and that the Early Triassic was an interval of repeated environmental disturbances (Algeo et al., 2011; Retallack et al., 2011) and elevated global temperatures (Sun et al., 2012; Romano et al., 2013) linked to volcanogenic greenhouse gas emissions (Retallack and Jahren, 2008; Black et al., 2012), the obvious explanation for the SSB is a reduction in the intensity of magmatic activity in the STLIP source region (Fig. 6). The available radiometric age data for the Siberian Traps, although sparse, are consistent with this possibility. U-Pb dating of perovskites in the early Arydzhangsky flow and zircons from the late Delkansky silicic tuff of extrusive suites in the Maymecha-Kotuy region suggests that the STLIP flood basalt eruptions commenced at $251.7 \pm 0.4 \mathrm{Ma}$ and ended at $251.1 \pm 0.3 \mathrm{Ma}$, i.e., representing an interval of $\sim 600 \mathrm{kyr}$ (Renne et al., 1995; Kamo et al., 2003). However, an Ar-Ar date of $250.3 \pm 1.1$ Ma was obtained for the final stage of extrusive volcanism at Norilsk, the core area of the STLIP (Reichow et al., 2009; see also the review of evidence for a late eruptive stage by Ovtcharova et al., 2006). The more critical issue, in any case, is the duration not of flood basalt eruptions but of intrusive magmatism in the West Siberian Coal Basin, which was probably the main source of volcanogenic greenhouse gases (Retallack and Jahren, 2008; Black et al., 2012). Reichow et al. (2009) reported ages for STLIP-related intrusives spanning several million years, which is consistent with the hypotheses that large-scale intrusive activity continued at least until the SSB and that cessation of most such activity at the SSB was responsible for contemporaneous climatic cooling (Sun et al., 2012; Romano et al., 2013). Further work on the chronology of the STLIP will be needed to conclusively evaluate controls on the SSB event. 


\section{Conclusions}

The SSB event (late Early Triassic) was investigated at Shitouzhai, Guizhou Province, South China, using a multidisciplinary approach combining carbonate carbon $\left(\delta^{13} \mathrm{C}_{\text {carb }}\right)$ and carbonate-associated sulfate sulfur isotopes $\left(\delta^{34} \mathrm{~S}_{\mathrm{CAS}}\right)$, rare earth elements, and elemental paleoredox and paleoproductivity proxies. The Shitouzhai section exhibits a large $(+4 \%$ o $)$ positive $\delta^{13} C_{\text {carb }}$ shift across the SSB similar to that seen in other SSB sections globally, reflecting enhanced marine productivity and organic carbon burial. Various elemental and isotopic proxies also document a major decrease in chemical weathering intensity and detrital sediment input, a shift toward a better-ventilated oceanic thermocline, and a diminished burial flux of reduced sulfur. All of these changes coincided with a large cooling of sea-surface temperatures that terminated the Early Triassic hothouse regime. The extreme temperatures of the late Smithian thermal maximum (LSTM) may have triggered a biocrisis just prior to the SSB. Marine biotas did not recover immediately in response to climatic and environmental amelioration at the SSB, however, but underwent a stepwise recovery during the early to middle Spathian. The cause of the SSB event is uncertain but may have been related to a reduction in intrusive magmatic activity in the Siberian Traps large igneous province. 


\section{Appendix A: Geologic and paleontologic background}

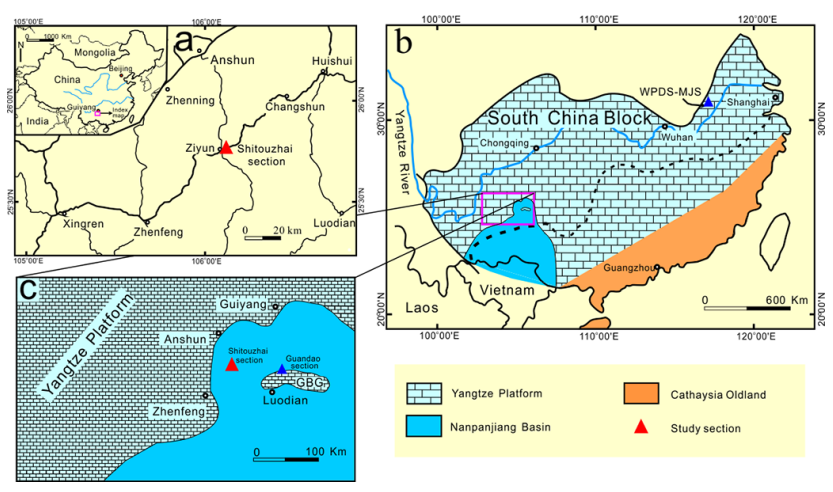

Figure A1. (a) Geographic map of southern Guizhou Province, South China, showing location of the Shitouzhai section in Ziyun County (modified from the Geographic Map of China, http://map. baidu.com). The red rectangle in the inset map of China shows the location of the study area. Early Triassic paleogeography of (b) the South China block and (c) the study area (modified from Feng et al., 1997). Note that the locations of the West Pingdingshan (WPDS) and Majiashan (MJS) sections are shown in (b) and that of the Guandao section in (c). GBG stands for Great Bank of Guizhou.

The study section is located at Shitouzhai village (GPS: $25^{\circ} 45^{\prime} 9.6^{\prime \prime} \mathrm{N}, 106^{\circ} 6^{\prime} 29.7^{\prime \prime} \mathrm{E}$ ), about $3 \mathrm{~km}$ east of Ziyun County town in southern Guizhou Province, South China (Fig. A1). During the Early to Middle Triassic, the Ziyun area was located on the southern margin of the Yangtze Platform, to the north of the Nanpanjiang Basin (Enos et al., 2006). The paleogeographic configuration of the Ziyun area changed from a platform-margin reef system in the latest Permian to a platform-ramp environment in the Early Triassic (Feng et al., 1997). In this area of the Nanpanjiang Basin in southern Guizhou Province, the Upper Permian successions usually comprise bioclastic rocks, which are collectively assigned to the Wujiaping Formation. However, unlike the same formation exposed elsewhere in South China, which is confined to the Wuchiapingian Stage of the late Permian, the Wujiaping Formation in the Nanpanjiang Basin yields biotas of Wuchiapingian and Changhsingian age. This means that, in the study area, the Changxing Formation of Changhsingian age cannot be separated on the basis of lithology from the $\mathrm{Wu}$ jiaping Formation. In most areas of the Nanpanjiang Basin, the contact of Upper Permian limestones with the overlying Lower Triassic Luolou Formation is conformable, although karstic phenomena may occur locally due to the end-Permian regional regression that affected the entire South China Block (Yin et al., 2014).
At Shitouzhai, Upper Permian to Middle Triassic strata are assigned to the Wujiaping, Luolou, and Xinyuan formations, in ascending order (Ding and Huang, 1990). The upper Wujiaping Formation consists largely of massive sponge reef limestone and yields the fusulinid Paleofusulina sinse and the conodont Clarkina changxingensis, both of which point to a late Changhsingian age (Ding and Huang, 1990; Shen and $\mathrm{Xu}, 2005$; Wu et al., 2010). The Luolou Formation is composed of thin-bedded calcareous mudstone, muddy limestone, and vermicular limestone with interbeds of breccia, from which conodont zones of definite Early Triassic age have been established (Ding and Huang, 1990). The lower Xinyuan Formation is also well exposed and consists of thinbedded calcareous mudstone, yielding small bivalves of Middle Triassic age (Ding and Huang, 1990). 


\section{Appendix B: Assessment of diagenesis}

We evaluated the potential diagenetic alteration of the carbonate beds in the Shitouzhai based on $\mathrm{Mn}$ and $\mathrm{Sr}$ concentrations and ratios. Diagenesis of marine carbonates generally results in an increase in $\mathrm{Mn}$ and a loss of $\mathrm{Sr}$ (Huang et al., 2003; Hu et al., 2010). In general, $\mathrm{Mn} / \mathrm{Sr}$ ratios < 3 are indicative of minimal diagenetic alteration, suggesting that elemental and isotopic signals are representative of the original chemistry of the sediment (Brand, 2004; Dehler et al., 2005; Le Guerroué et al., 2006). Primary $\delta^{13} \mathrm{C}$ values can be retained through diagenesis to $\mathrm{Mn} / \mathrm{Sr}$ ratios as high as 10 (Shen, 2002; Le Guerroué et al., 2006). The relatively low $\mathrm{Mn} / \mathrm{Sr}$ ratios of the study section (mostly <2; Appendix C) are evidence of relatively limited diagenetic alteration. Note that we calculated both whole-rock and carbonate $\mathrm{Mn} / \mathrm{Sr}$ ratios and found little variation between them: their distributions (as given by 16th, 50th, and 84th percentile values) are $0.16,0.39$, and 2.70 for whole-rock $\mathrm{Mn} / \mathrm{Sr}$ and 0.10, 0.35, and 2.76 for carbonate $\mathrm{Mn} / \mathrm{Sr}$. The similarity of whole-rock and carbonate values is due to the limited amounts of detrital Mn (estimated at $8.1 \pm 4.4 \%$ of whole-rock $\mathrm{Mn}$ ) and detrital $\operatorname{Sr}(4.0 \pm 2.2 \%$ of whole-rock $\mathrm{Sr})$ in the samples.

Conservation of the original $\delta^{13} \mathrm{C}_{\mathrm{carb}}$ of the samples is also evidenced by relative ${ }^{18} \mathrm{O}$ enrichment (i.e., $\delta^{18} \mathrm{O}$ heavier than $-5 \%$; Appendix C), which is close to primary marine $\mathrm{O}$ isotope values (ca. 0 $\pm 5 \%$; Algeo et al., 1992; Zhao and Zheng, 2011). Diagenetic alteration that is only limited is also indicated by the lack of covariation between $\mathrm{Mn} / \mathrm{Sr}$ and $\delta^{18} \mathrm{O}_{\text {carb }}$ for both Smithian $\left(r^{2}=0.05\right)$ and Spathian samples $\left(r^{2}=0.01\right.$; Fig. B1a) as well as between $\mathrm{Mn} / \mathrm{Sr}$ and $\delta^{13} \mathrm{C}_{\text {carb }}$ for both Smithian $\left(r^{2}=0.32\right)$ and Spathian samples $\left(r^{2}=0.00\right.$; Fig. B $\left.1 b\right) . \mathrm{Mn} / \mathrm{Sr}$ exhibits stronger covariation with both $\delta^{18} \mathrm{O}_{\text {carb }}$ and $\delta^{13} \mathrm{C}_{\text {carb }}$ for the full sample set, although this variation mainly reflects secular differences in $\mathrm{O}$ and $\mathrm{C}$-isotopic compositions between Smithian and Spathian samples rather than diagenetic effects. No significant covariation between $\delta^{18} \mathrm{O}_{\text {carb }}$ and $\delta^{13} \mathrm{C}_{\text {carb }}$ is seen in Smithian $\left(r^{2}=0.00\right)$ and Spathian $\left(r^{2}=0.09\right)$ samples (Fig. B1c). Little or no covariation between $\mathrm{Mn} / \mathrm{Sr}$ and $\delta^{34} \mathrm{~S}_{\mathrm{CAS}}$ exists for the Smithian $\left(r^{2}=0.02\right)$ and Spathian $\left(r^{2}=0.06\right)$ samples (Fig. B1d). This means that CAS from the study section was subject to minimal diagenetic influences. Covariation between $\delta^{34} \mathrm{~S}_{\mathrm{CAS}}$ and CAS concentration is weak $\left(r^{2}=0.06\right.$ and 0.40 for Smithian and Spathian samples, respectively; Fig. B1e), suggesting that little pyrite oxidation occurred during the CAS extraction procedure. If significant amounts of pyrite sulfur had been admixed through oxidation, $\delta^{34} \mathrm{~S}_{\mathrm{CAS}}$ values would have been lowered considerably relative to the actual CAS isotopic composition (cf. Marenco et al., 2008). In fact, the $\delta^{34} \mathrm{~S}_{\mathrm{CAS}}$ values reported here are similar to those obtained from other Early Triassic studies (Song et al., 2014). We therefore infer that both the carbon and sulfur isotope profiles for the Shitouzhai section have largely preserved original marine compositions.
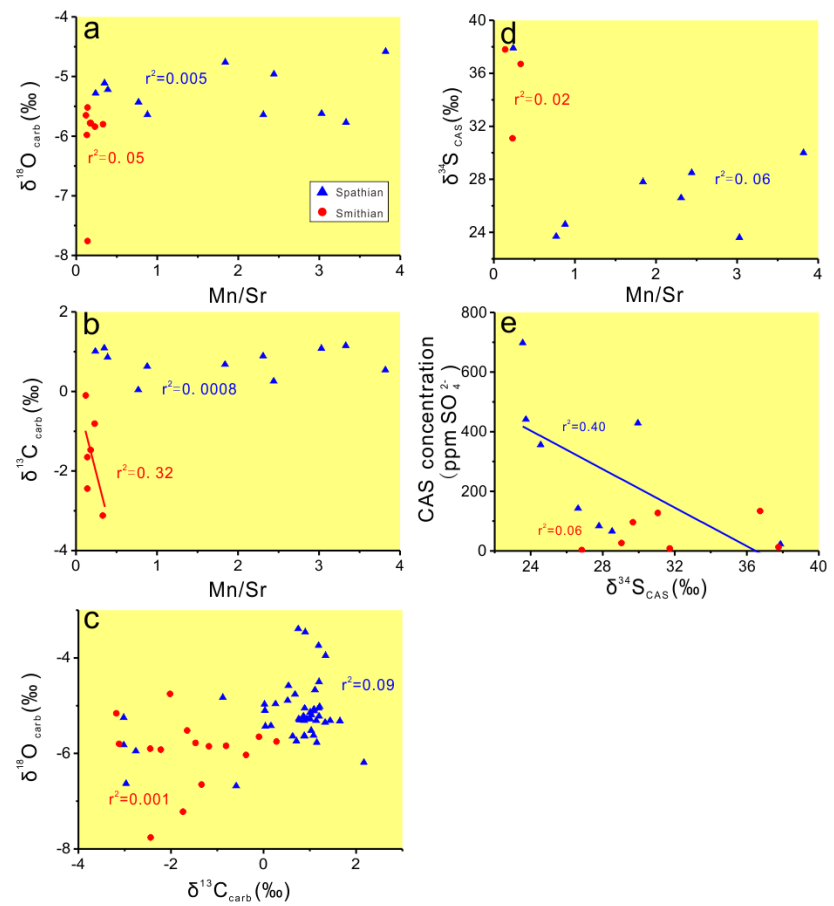

Figure B1. Elemental and stable isotope crossplots: (a) $\delta^{18} \mathrm{O}_{\text {carb }}$ vs. $\mathrm{Mn} / \mathrm{Sr}$ ratio; (b) $\delta^{13} \mathrm{C}_{\text {carb }}$ vs. $\mathrm{Mn} / \mathrm{Sr}$ ratio; (c) $\delta^{18} \mathrm{O}_{\text {carb }}$ vs. $\delta^{13} \mathrm{C}_{\text {carb }}$; (d) $\delta^{34} \mathrm{~S}_{\mathrm{CAS}}$ vs. $\mathrm{Mn} / \mathrm{Sr}$ ratio; (e) CAS concentrations vs. $\delta^{34} \mathrm{~S}_{\text {CAS }}$. CAS (carbonate-associated sulfate) concentration is given as $\mathrm{ppm}_{4}^{2-}$. 
Appendix C: Elemental and isotopic data for the

Shitouzhai section

Table C1. Isotopic and trace element data for the Shitouzhai section.

\begin{tabular}{|c|c|c|c|c|c|c|c|c|}
\hline Sample & Height (m) & $\begin{array}{r}\delta^{13} \mathrm{C}_{\text {carb }}(\% o) \\
\text { VPDB }\end{array}$ & $\begin{array}{r}\delta^{18} \mathrm{O}(\%) \\
\mathrm{VPDB}\end{array}$ & $\begin{array}{r}\delta^{34} \mathrm{~S}_{\mathrm{CAS}}(\%) \\
\mathrm{VCDT}\end{array}$ & $\begin{array}{r}\text { CAS concentration } \\
\left(\mathrm{ppm} \mathrm{SO}_{4}^{2-}\right) \\
(\mathrm{BaSO} 4, \mathrm{ppm})\end{array}$ & $\begin{array}{r}\mathrm{Mn} \\
(\mathrm{ppm})\end{array}$ & $\begin{array}{r}\mathrm{Sr} \\
(\mathrm{ppm})\end{array}$ & $\mathrm{Mn} / \mathrm{Sr}$ \\
\hline STZT2-12 & 72.7 & -0.59 & -6.68 & & & & & \\
\hline STZT2-11 & 67.7 & -0.88 & -4.83 & & & & & \\
\hline STZT2-9 & 65.6 & -2.76 & -5.95 & & & & & \\
\hline STZT2-8 & 61.2 & 0.02 & -4.97 & & & & & \\
\hline STZT2-6 & 59.7 & -3.02 & -5.25 & & & & & \\
\hline STZT2-4 & 54.7 & -2.97 & -6.63 & & & & & \\
\hline STZT2-2 & 45.7 & 0.03 & -8.45 & & & & & \\
\hline STZT2-1 & 44.9 & -3.02 & -5.82 & & & & & \\
\hline S5TZT-1 & 44.5 & 2.17 & -6.19 & & & & & \\
\hline S1TZT-25 & 44.3 & 1.2 & -4.50 & & & & & \\
\hline S1TZT-24 & 42.3 & 1.2 & -5.22 & & & & & \\
\hline S5TZT-2 & 41.5 & 0.76 & -5.28 & & & & & \\
\hline S1TZT-23 & 41.3 & 1.44 & -5.31 & & & & & \\
\hline S5TZT-3 & 40.6 & 1.19 & -5.05 & & & & & \\
\hline S1TZT-22 & 40.3 & 1.03 & -5.52 & & & & & \\
\hline S5TZT-4 & 40 & 1.33 & -5.35 & & & & & \\
\hline S1TZT-21 & 39.3 & 0.88 & -5.63 & 24.56 & 356 & & & \\
\hline S5TZT-5 & 39 & 1.14 & -5.31 & & & & & \\
\hline S1TZT-20 & 38.3 & 0.63 & -5.64 & & & 793 & 898 & 0.88 \\
\hline S5TZT-6 & 38 & 0.88 & -5.31 & & & & & \\
\hline S1TZT-19 & 37.3 & 1.01 & -5.14 & & & & & \\
\hline S1TZT-18 & 36.3 & 0.89 & -5.64 & 26.64 & 143 & 1891 & 820 & 2.31 \\
\hline S1TZT-17 & 35.3 & 1.65 & -5.32 & & & & & \\
\hline S1TZT-16 & 34.3 & 1.15 & -5.77 & & & 3776 & 1134 & 3.33 \\
\hline S1TZT-15 & 33.3 & 1.34 & -3.95 & & & & & \\
\hline S1TZT-14 & 32.3 & 0.86 & -5.22 & & & 447 & 1141 & 0.39 \\
\hline S1TZT-13 & 31.3 & 1.09 & -5.07 & 37.87 & 23 & & & \\
\hline S1TZT-12 & 30.3 & 1.01 & -5.28 & & & 296 & 1210 & 0.24 \\
\hline S1TZT-11 & 29.3 & 0.78 & -5.3 & & & & & \\
\hline S1TZT-10 & 28.3 & 1.09 & -5.11 & & & 304 & 857 & 0.35 \\
\hline S4TZT-4 & 28.3 & 0.89 & -5.05 & & & & & \\
\hline S4TZT-3 & 28.1 & 0.87 & -5.24 & & & & & \\
\hline S4TZT-2 & 27.8 & 0.93 & -5.27 & & & & & \\
\hline S4TZT-1 & 27.5 & 0.71 & -5.74 & & & & & \\
\hline S1TZT-9 & 27.3 & 0.16 & -5.42 & & & & & \\
\hline S3TZT-1 & 27.2 & 1.11 & -4.67 & & & & & \\
\hline S3TZT-2 & 26.9 & 1.08 & -5.62 & 23.56 & 698 & 1609 & 531 & 3.03 \\
\hline S3TZT-3 & 26.6 & 0.9 & -3.46 & & & & & \\
\hline S1TZT-8 & 26.2 & 0.75 & -3.39 & & & & & \\
\hline S3TZT-4 & 25.8 & 1.19 & -3.74 & & & & & \\
\hline S1TZT-7 & 25.2 & 0.68 & -4.76 & & & 1509 & 821 & 1.84 \\
\hline S1TZT-6 & 24.2 & 1.21 & -5.02 & 27.79 & 84 & & & \\
\hline S1TZT-5 & 23.2 & 0.26 & -4.96 & & & 1841 & 756 & 2.44 \\
\hline S1TZT-4 & 22.2 & 0.52 & -4.89 & & & & & \\
\hline S1TZT-3 & 21.2 & 0.54 & -4.58 & & & 1943 & 508 & 3.82 \\
\hline S1TZT-2 & 20.2 & 0.03 & -5.1 & 28.52 & 66 & & & \\
\hline S1TZT-1 & 19.2 & 1.03 & -5.19 & 29.95 & 429 & & & \\
\hline S2TZT-1 & 19.1 & 0.04 & -5.43 & 23.73 & 441 & 1046 & 1367 & 0.77 \\
\hline S2TZT-2 & 18.1 & -1.18 & -5.85 & 26.83 & 3 & & & \\
\hline S2TZT-3 & 17.1 & -3.12 & -5.8 & 36.74 & 134 & 375 & 1131 & 0.33 \\
\hline S2TZT-4 & 16.1 & -2.22 & -5.92 & & & & & \\
\hline S2TZT-5 & 15.1 & -2.02 & -4.753 & & & & & \\
\hline S2TZT-6 & 14.1 & -1.65 & -5.52 & 37.76 & 12 & 230 & 1609 & 0.14 \\
\hline S2TZT-7 & 13.1 & -2.45 & -5.9 & & & & & \\
\hline S2TZT-8 & 12.1 & -2.44 & -7.76 & & & 230 & 1609 & 0.14 \\
\hline S2TZT-9 & 11.1 & -3.18 & -5.16 & 29.67 & 97 & & & \\
\hline S2TZT-10 & 9.1 & -1.47 & -5.78 & & & 377 & 2095 & 0.18 \\
\hline S2TZT-11 & 8.1 & -1.34 & -6.65 & & & & & \\
\hline STZT-28 & 6.5 & -0.38 & -6.03 & 31.06 & 128 & & & \\
\hline STZT-27 & 4.9 & -0.81 & -5.84 & & & 391 & 1672 & 0.23 \\
\hline STZT-26 & 3.3 & 0.28 & -5.75 & 31.72 & 8 & & & \\
\hline STZT-25 & 1.8 & -1.74 & -7.22 & 29.04 & 27 & & & \\
\hline STZT-24 & 0 & -0.1 & -5.65 & & & 254 & 2160 & 0.12 \\
\hline
\end{tabular}


Table C2. Major and trace element concentrations and ratios for the Shitouzhai section.

\begin{tabular}{|c|c|c|c|c|c|c|c|c|c|c|c|c|c|c|c|c|c|}
\hline Sample & $\begin{array}{l}\text { S1TZT-20 } \\
\end{array}$ & $\begin{array}{l}\text { S1TZT-18 } \\
\end{array}$ & S1TZT-16 & S1TZT-14 & $\begin{array}{l}\text { S1TZT-12 } \\
\end{array}$ & S1TZT-10 & $\begin{array}{l}\text { S3TZT-2 } \\
\text { S3T }\end{array}$ & $\begin{array}{l}\text { S1TZT-7 } \\
\end{array}$ & S1TZT-5 & $\begin{array}{l}\text { S1TZT-3 } \\
\end{array}$ & S2TZT-1 & S2TZT-3 & $\begin{array}{l}\text { S2TZT-6 } \\
\end{array}$ & $\begin{array}{l}\text { S2TZT-8 } \\
\text { S2T }\end{array}$ & $\begin{array}{l}\text { S2TZT-10 } \\
\end{array}$ & $\begin{array}{l}\text { STZT-27 } \\
\end{array}$ & STZT-24 \\
\hline Age(Ma) & 249.64 & 249.74 & 249.83 & 249.93 & 250.02 & 250.12 & 250.18 & 250.27 & 250.36 & 250.46 & 250.55 & 250.60 & 250.67 & 250.72 & 250.79 & 250.88 & 251.00 \\
\hline Depth(m) & 38.3 & 36.3 & 34.3 & 32.3 & 30.3 & 28.3 & 26.9 & 25.2 & 23.2 & 21.2 & 19.13 & 17.13 & 14.13 & 12.13 & 9.13 & 4.93 & 0 \\
\hline $\mathrm{La}$ & 5.00 & 4.34 & 4.93 & 6.05 & 7.72 & 5.01 & 6.05 & 4.54 & 3.89 & 2.73 & 8.35 & 7.99 & 6.05 & 9.50 & 11.59 & 9.73 & 9.11 \\
\hline $\mathrm{Ce}$ & 8.46 & 7.50 & 8.29 & 10.37 & 13.23 & 8.54 & 9.40 & 7.48 & 6.77 & 5.03 & 15.85 & 14.74 & 11.24 & 17.71 & 21.63 & 17.95 & 16.91 \\
\hline $\operatorname{Pr}$ & 1.11 & 0.91 & 1.01 & 1.34 & 1.74 & 1.10 & 1.39 & 0.95 & 0.80 & 0.61 & 1.96 & 1.77 & 1.39 & 2.16 & 2.64 & 2.20 & 2.16 \\
\hline $\mathrm{Nd}$ & 4.34 & 3.43 & 3.81 & 5.20 & 6.70 & 4.35 & 5.23 & 3.68 & 3.23 & 2.28 & 7.46 & 6.95 & 5.45 & 8.39 & 10.13 & 8.65 & 8.72 \\
\hline $\mathrm{Sm}$ & 0.84 & 0.64 & 0.71 & 1.03 & 1.36 & 0.89 & 1.18 & 0.71 & 0.61 & 0.46 & 1.60 & 1.51 & 1.08 & 1.85 & 2.26 & 1.78 & 1.92 \\
\hline $\mathrm{Eu}$ & 0.17 & 0.12 & 0.15 & 0.21 & 0.25 & 0.18 & 0.24 & 0.16 & 0.12 & 0.10 & 0.30 & 0.30 & 0.23 & 0.35 & 0.41 & 0.36 & 0.39 \\
\hline $\mathrm{Gd}$ & 0.83 & 0.63 & 0.68 & 0.96 & 1.22 & 0.80 & 1.13 & 0.76 & 0.55 & 0.39 & 1.47 & 1.31 & 1.02 & 1.64 & 1.92 & 1.66 & 1.78 \\
\hline $\mathrm{Tb}$ & 0.13 & 0.09 & 0.11 & 0.14 & 0.18 & 0.12 & 0.18 & 0.11 & 0.09 & 0.07 & 0.23 & 0.21 & 0.17 & 0.24 & 0.31 & 0.25 & 0.27 \\
\hline Dy & 0.77 & 0.62 & 0.67 & 0.84 & 1.11 & 0.71 & 1.08 & 0.60 & 0.56 & 0.41 & 1.30 & 1.25 & 1.02 & 1.35 & 1.77 & 1.53 & 1.58 \\
\hline Но & 0.15 & 0.12 & 0.14 & 0.17 & 0.20 & 0.13 & 0.22 & 0.14 & 0.11 & 0.08 & 0.25 & 0.24 & 0.20 & 0.26 & 0.35 & 0.31 & 0.30 \\
\hline $\mathrm{Er}$ & 0.41 & 0.33 & 0.43 & 0.48 & 0.56 & 0.40 & 0.59 & 0.42 & 0.33 & 0.24 & 0.75 & 0.72 & 0.56 & 0.74 & 0.99 & 0.79 & 0.91 \\
\hline $\mathrm{Tm}$ & 0.06 & 0.05 & 0.06 & 0.06 & 0.08 & 0.06 & 0.08 & 0.06 & 0.05 & 0.03 & 0.11 & 0.08 & 0.08 & 0.11 & 0.14 & 0.12 & 0.12 \\
\hline $\mathrm{Yb}$ & 0.36 & 0.28 & 0.36 & 0.40 & 0.50 & 0.37 & 0.55 & 0.37 & 0.27 & 0.20 & 0.66 & 0.53 & 0.47 & 0.67 & 0.89 & 0.76 & 0.71 \\
\hline $\mathrm{Lu}$ & 0.05 & 0.05 & 0.05 & 0.06 & 0.08 & 0.05 & 0.08 & 0.06 & 0.04 & 0.03 & 0.09 & 0.08 & 0.07 & 0.10 & 0.12 & 0.11 & 0.12 \\
\hline $\mathrm{Y}$ & 5.37 & 4.05 & 4.82 & 5.65 & 6.80 & 4.87 & 7.87 & 5.25 & 3.72 & 2.78 & 8.51 & 7.98 & 6.93 & 9.23 & 11.2 & 9.48 & 9.94 \\
\hline Th & 1.14 & 1.16 & 1.30 & 1.69 & 1.97 & 1.36 & 1.47 & 1.25 & 1.23 & 0.83 & 2.36 & 2.81 & 1.65 & 2.99 & 3.96 & 3.29 & 2.86 \\
\hline $\mathrm{U}$ & 2.02 & 1.42 & 1.23 & 1.76 & 2.22 & 2.24 & 2.57 & 3.74 & 3.22 & 2.46 & 2.83 & 1.99 & 2.11 & 2.06 & 2.53 & 2.49 & 2.34 \\
\hline $\mathrm{Al}_{2} \mathrm{O}_{3}$ & 1.01 & 1.02 & 1.19 & 1.46 & 1.67 & 1.12 & 1.51 & 1.31 & 1.41 & 0.77 & 2.72 & 3.31 & 2.21 & 3.41 & 4.19 & 3.96 & 3.06 \\
\hline $\mathrm{K}_{2} \mathrm{O}$ & 0.26 & 0.29 & 0.34 & 0.43 & 0.5 & 0.32 & 0.44 & 0.4 & 0.46 & 0.23 & 0.76 & 0.94 & 0.57 & 0.89 & 1.11 & 1.04 & 0.85 \\
\hline $\mathrm{Na}_{2} \mathrm{O}$ & 0.14 & 0.12 & 0.15 & 0.13 & 0.14 & 0.11 & 0.18 & 0.1 & 0.1 & 0.11 & 0.13 & 0.12 & 0.07 & 0.22 & 0.15 & 0.15 & 0.08 \\
\hline$\sum$ REE & 22.7 & 19.1 & 21.4 & 27.3 & 34.9 & 22.7 & 27.4 & 20.0 & 17.4 & 12.7 & 40.4 & 37.7 & 29.0 & 45.1 & 55.2 & 46.2 & 45.0 \\
\hline $\mathrm{Ce} / \mathrm{Ce}^{*}$ & 0.79 & 0.83 & 0.82 & 0.80 & 0.80 & 0.80 & 0.73 & 0.79 & 0.83 & 0.87 & 0.88 & 0.86 & 0.86 & 0.87 & 0.87 & 0.86 & 0.84 \\
\hline $\mathrm{Eu} / \mathrm{Eu}^{*}$ & 0.97 & 0.90 & 1.03 & 1.01 & 0.95 & 1.02 & 1.01 & 1.05 & 1.02 & 1.20 & 0.94 & 1.03 & 1.06 & 0.97 & 0.96 & 1.01 & 1.02 \\
\hline $\mathrm{Th} / \mathrm{Th}^{*}$ & 0.106 & 0.108 & 0.121 & 0.158 & 0.184 & 0.127 & 0.138 & 0.117 & 0.115 & 0.078 & 0.221 & 0.263 & 0.155 & 0.279 & 0.370 & 0.307 & 0.268 \\
\hline $\mathrm{Mn} / \mathrm{Th}$ & 699 & 1630 & 2909 & 265 & 151 & 223 & 1092 & 1205 & 1491 & 2343 & 442 & 133 & 139 & 191 & 95 & 119 & 89 \\
\hline $\mathrm{Sm}_{\mathrm{N}} / \mathrm{Yb}_{\mathrm{N}}$ & 1.17 & 1.13 & 0.99 & 1.28 & 1.37 & 1.21 & 1.08 & 0.98 & 1.14 & 1.18 & 1.21 & 1.42 & 1.14 & 1.38 & 1.27 & 1.17 & 1.35 \\
\hline $\mathrm{Th} / \mathrm{U}$ & 0.56 & 0.82 & 1.06 & 0.96 & 0.89 & 0.61 & 0.57 & 0.34 & 0.38 & 0.34 & 0.84 & 1.42 & 0.78 & 1.45 & 1.56 & 1.32 & 1.22 \\
\hline $\mathrm{Y} / \mathrm{Ho}$ & 35.70 & 34.16 & 35.05 & 33.59 & 33.27 & 36.83 & 35.01 & 37.17 & 34.66 & 34.72 & 33.73 & 33.94 & 35.05 & 35.05 & 31.50 & 30.70 & 33.69 \\
\hline LSR & 21.07 & 21.07 & 21.07 & 21.07 & 21.07 & 21.07 & 21.07 & 21.07 & 21.07 & 21.25 & 28.37 & 42.64 & 42.64 & 42.64 & 42.64 & 42.64 & 42.64 \\
\hline BAR & 5.27 & 5.27 & 5.27 & 5.27 & 5.27 & 5.27 & 5.27 & 5.27 & 5.27 & 5.31 & 7.09 & 10.66 & 10.66 & 10.66 & 10.66 & 10.66 & 10.66 \\
\hline Clay MAR & 0.56 & 0.57 & 0.64 & 0.83 & 0.97 & 0.67 & 0.73 & 0.62 & 0.61 & 0.41 & 1.57 & 2.80 & 1.65 & 2.98 & 3.94 & 3.28 & 2.85 \\
\hline Carb MAR & 4.71 & 4.70 & 4.63 & 4.43 & 4.30 & 4.60 & 4.54 & 4.65 & 4.66 & 4.90 & 5.52 & 7.86 & 9.01 & 7.68 & 6.72 & 7.38 & 7.81 \\
\hline CIA & 0.72 & 0.71 & 0.71 & 0.72 & 0.72 & 0.72 & 0.71 & 0.72 & 0.72 & 0.69 & 0.75 & 0.76 & 0.78 & 0.75 & 0.77 & 0.77 & 0.77 \\
\hline
\end{tabular}


Author contributions. Z. Q. Chen, L. S. Zhao and L. Zhang conceived the study. L. Zhang and Y. Li undertook the fieldwork and sample analysis. All authors assisted in data interpretation and the drafting of the manuscript.

Acknowledgements. The authors are grateful to Chao Li, Jianbo Chen, Run Wang, Jing Hou, Hui Qiu, Derong Ma, Lei Shi, and Yuheng Fang for assistance with sample preparation and laboratory analysis. This study is supported by NSFC grants (nos. 41272025, 41272040, and 41473006). Z. Q. Chen's work is supported by the 973 Program of China (2011CB808800), the 111 Program of China (B08030), and research grants from both SKLGPMR and SKLBGEG (GPMR201302 and GBL11206). T. J. Algeo gratefully acknowledges support from the Sedimentary Geology and Paleobiology program of the US National Science Foundation, the NASA Exobiology program, and the State Key Laboratory of Geological Processes and Mineral Resources, China University of Geosciences, Wuhan (program GPMR201301).

Edited by: W. Kiessling

\section{References}

Algeo, T. J. and Maynard, J. B.: Trace element behavior and redox facies in core shales of Upper Pennsylvanian Kansas-type cyclothems, Chem. Geol., 206, 289-318, 2004.

Algeo, T. J. and Twitchett, R. J.: Anomalous Early Triassic sediment fluxes due to elevated weathering rates and their biological consequences, Geology, 38, 1023-1026, 2010.

Algeo, T. J., Wilkinson, B. H., and Lohmann, K. C.: Meteoric-burial diagenesis of Middle Pennsylvanian limestones in the Orogrande Basin, New Mexico: water/rock interactions and basin geothermics, J. Sediment. Petrol., 62, 652-670, 1992.

Algeo, T. J., Chen, Z. Q., Fraiser, M. L., and Twitchett, R. J.: Terrestrial-marine teleconnections in the collapse and rebuilding of Early Triassic marine ecosystems, Palaeogeogr. Palaeocl., 308, 1-11, 2011.

Bau, M.: Controls on the fractionation of isovalent trace elements in magmatic and aqueous systems: evidence from $\mathrm{Y} / \mathrm{Ho}, \mathrm{Zr} / \mathrm{Hf}$, and lanthanide tetrad effect, Contrib. Mineral Petr., 123, 323333, 1996

Black, B. A., Elkins-Tanton, L. T., Rowe, M. C., and Ukstins Peate, I.: Magnitude and consequences of volatile release from the Siberian Traps, Earth Planet. Sc. Lett., 317-318, 363-373, 2012.

Bottjer, D. J., Clapham, M. E., Fraiser, M. L., and Powers, C. M.: Understanding mechanisms for the end-Permian mass extinction and the protracted Early Triassic aftermath and recovery, GSA Today, 18, 4-10, 2008.

Brand, U.: Carbon, oxygen and strontium isotopes in Paleozoic carbonate components: an evaluation of original seawater-chemistry proxies, Chem. Geol., 204, 23-44, 2004.

Brayard, A., Escarguel, G., Bucher, H., Monnet, C., Brühwiler, T., Goudemand, N., Galfetti, T., and Guex, J.: Good genes and good luck: Ammonoid diversity and the end-Permian mass extinction, Science, 325, 1118-1121, 2009.
Bright, C. A., Cruse, A. M., Lyons, T. W., MacLeod, K. G., Glascock, M. D., and Ethington, R. L.: Seawater rare-earth element patterns preserved in apatite of Pennsylvanian conodonts?, Geochim. Cosmochim. Ac., 73, 1609-1624, 2009.

Chen, Y. L., Twitchett, R. J., Jiang, H. S., Richoz, S., Lai, X. L., Yan, C. B., Sun, Y. D., Liu, X. D., and Wang, L.: Size variation of conodonts during the Smithian-Spathian (Early Triassic) global warming event, Geology, 41, 823-826, 2013.

Chen, Z. Q. and Benton, M. J.: The timing and pattern of biotic recovery following the end-Permian mass extinction, Nat. Geosci., 5, 375-383, 2012.

Claypool, G. E., Holser, W. T., Kaplan, I. R., Sakai, H., and Zak, I.: The age curves of sulfur and oxygen isotopes in marine sulfate and their mutual interpretation, Chem. Geol., 28, 199-260, 1980.

Dehler, C. M., Elrick, M., Bloch, J. D., Crossey, L. J., Karlstrom, K. E., and Des Marais, D. J.: High-resolution $\delta^{13} \mathrm{C}$ stratigraphy of the Chuar Group (ca. 770-742 Ma), Grand Canyon: Implications for mid-Neoproterozoic climate change, Geol. Soc. Am. Bull., 117, 32-45, 2005.

Ding, M. H. and Huang, Q. H.: Late Permian-Middle Triassic conodonts fauna and paleoecology in Shitouzhai, Ziyun County, Guizhou Province, Earth Sci.-Jour. China Univ. Geosci., 15, 291-299, 1990.

Enos, P., Lehrmann, D. J., Wei, J. Y., Yu, Y. Y., Xiao, J. F., Chaikin, D. H., Minzoni, M., Berry, A. K., and Montgomery, P.: Triassic evolution of the Yangtze Platform in Guizhou Province, People's Republic of China, Geol. Soc. Am. Spec. Pap., 417, 1-105, 2006.

Erwin, D. H.: Lessons from the past: biotic recoveries from mass extinctions, P. Natl. Acad. Sci. USA, 98, 5399-5403, 2001.

Feng, Z. Z., Bao, Z. D., Wu, S. H., Li, Y. T., and Wang, G. L.: Lithofacies palaeogeography of the Early and Middle Triassic of South China, Sci. Geol. Sinica, 32, 212-220, 1997.

Galfetti, T., Hochuli, P. A., Brayard, A., Bucher, H., Weissert, H., and Vigran, J. O.: Smithian-Spathian boundary event: Evidence for global climatic change in the wake of the end-Permian biotic crisis, Geology, 35, 291-294, 2007.

German, C. R. and Elderfield, H.: Application of the Ce anomaly as a paleoredox indicator: the ground rules, Paleoceanography, 5, 823-833, 1990.

Goldberg, K. and Humayun, M.: The applicability of the Chemical Index of Alteration as a paleoclimatic indicator: An example from the Permian of the Paraná Basin, Brazil, Palaeogeogr. Palaeoecol., 293, 175-183, 2010.

Grasby, S. E., Sanei, H., Beauchamp, B., and Chen, Z.: Mercury deposition through the Permo-Triassic biotic crisis, Chem. Geol., 351, 209-216, 2013.

Hermann, E., Hochuli, P. A., Méhay, S., Bucher, H., Brühwiler, T., Ware, D., Hautmann, M., Roohi, G., and Yaseen, A.: Organic matter and palaeoenvironmental signals during the Early Triassic biotic recovery: The Salt Range and Surghar Range records, Sediment. Geol., 234, 19-41, 2011.

Hochuli, P. A. and Vigran, J. O.: Climate variations in the Boreal Triassic inferred from palynological records from the Barents Sea, Palaeogeogr. Palaeoecol., 290, 20-42, 2010.

Hochuli, P. A., Hermann, E., Vigran, J. O., Bucher, H., and Weissert, H.: Rapid demise and recovery of plant ecosystems across the end-Permian extinction event, Global Planet. Change, 74, 144 $155,2010$. 
Horacek, M., Brandner, R., and Abart, R.: Carbon isotope record of the P/T boundary and the Lower Triassic in the Southern Alps: evidence for rapid changes in storage of organic carbon, Palaeogeogr. Palaeoecol., 252, 347-354, 2007.

Hu, Z. W., Huang, S. J., Huang, K. K., Sun, W., and Gong, Y. C.: Preservative evaluation of coeval seawater information for the Triassic marine carbonate rocks in the Huaying Mountain, eastern Sichuan, Geology in China, 37, 1374-1382, 2010.

Huang, S. J., Shi, H., Mao, X. D., Zhang, M., Shen, L. C., and Wu, W. H.: Diagenetic alteration of earlier Palaeozoic marine carbonate and preservation for the information of sea water, Journal of Chengdu University of Technology (Science \& Technology Edition), 30, 9-18, 2003.

Kamo, S. L., Czamanske, G. K., Amelin, Y., Fedorenko, V. A., Davis, D. W., and Trofimov, V. R.: Rapid eruption of Siberian flood-volcanic rocks and evidence for coincidence with the Permian-Triassic boundary and mass extinction at $251 \mathrm{Ma}$, Earth Planet. Sc. Lett., 214, 75-91, 2003.

Kampschulte, A. and Strauss, H.: The sulfur isotopic evolution of Phanerozoic seawater based on the analysis of structurally substituted sulfate in carbonates, Chem. Geol., 204, 255-286, 2004.

Kidder, D. L. and Eddy-Dilek, C. A.: Rare-earth element variation in phosphate nodules from Midcontinent Pennsylvanian cyclothems, J. Sediment. Res., 64, 584-592, 1994.

Kiehl, J. T. and Shields, C. A.: Climate simulation of the latest Permian: Implication for mass extinction, Geology, 33, 757-760, 2005.

Kurschner, W. M. and Herngreen, G. F. W.: Triassic palynology of central and northwestern Europe: A review of palynoflora diversity patterns and biostratigraphic subdivisions, Geol. Soc. London, Spec. Publ., 334, 263-283, 2010.

Landing, W. M. and Bruland, K. W.: The contrasting biogeochemistry of iron and manganese in the Pacific Ocean, Geochim. Cosmochim. Ac., 51, 29-43, 1987.

Langmuir, D.: Uranium solution-mineral equilibria at low temperatures with applications to sedimentary ore deposits, Geochim. Cosmochim. Ac., 42, 547-569, 1978.

Le Guerroué, E., Allen, P. A., and Cozzi, A.: Chemostratigraphic and sedimentological framework of the largest negative carbon isotopic excursion in Earth history: The Neoproterozoic Shuram Formation (Nafun Group, Oman), Prec. Res., 146, 68-92, 2006.

Lehrmann, D. J., Ramezani, J., Bowring, S. A., Martin, M. W., Montgomery, P., Enos, P., Payne, J. L., Orchard, M. J., Hongmei, W., and Jiayong, W.: Timing of recovery from the end-Permian extinction: Geochronologic and biostratigraphic constraints from south China, Geology, 34, 1053-1056, 2006.

Liang, D., Tong, J. N., and Zhao, L. S.: Lower Triassic SmithianSpathian boundary at West Pingdingshan section in Chaohu, Anhui Province, Sci. China Ser. D, 54, 372-379, 2011.

Liu, Y. S., Zong, K. Q., Kelemen, P. B., and Gao, S.: Geochemistry and magmatic history of eclogites and ultramafic rocks from the Chinese continental scientific drill hole: Subduction and ultrahigh-pressure metamorphism of lower crustal cumulates, Chem. Geol., 247, 133-153, 2008.

Looy, C. V., Brugman, W. A., Dilcher, D. L., and Visscher, H.: The delayed resurgence of equatorial forests after the PermianTriassic ecological crisis, P. Natl. Acad. Sci. USA, 96, 13857 13862, 1999.
Looy, C. V., Twitchett, R. J., Dilcher, D. L., Van Konijnenburg-Van Cittert, J. H. A., and Visscher, H.: Life in the end-Permian dead zone, P. Natl. Acad. Sci. USA, 98, 7879-7883, 2001.

Luo, G. M., Kump, L. R., Wang, Y. B., Tong, J. N., Arthur, M. A., Yang, H., Huang, J. H., Yin, H. F., and Xie, S. C.: Isotopic evidence for an anomalously low oceanic sulfate concentration following end-Permian mass extinction, Earth Planet. Sc. Lett., 300, 101-111, 2010.

Marenco, P. J., Corsetti, F. A., Hammond, D. E., Kaufman, A. J., and Bottjer, D. J.: Oxidation of pyrite during extraction of carbonate associated sulfate, Chem. Geol., 247, 124-132, 2008.

McLennan, S. M.: Relationships between the trace element composition of sedimentary rocks and upper continental crust, Geochem. Geophy. Geosy., 2, 2000GC000109, 2001.

Nesbitt, H. W. and Young, G. M.: Early Proterozoic climates and plate motions inferred from major element chemistry of lutites, Nature, 299, 715-717, 1982.

Okita, P. M., Maynard, J. B., Spiker, E. C., and Force, E. R.: Isotopic evidence for organic-matter oxidation by manganese reduction in the formation of stratiform manganese carbonate ore, Geochim Cosmochim. Ac., 52, 2679-2685, 1988.

Orchard, M. J.: Conodont diversity and evolution through the latest Permian and Early Triassic upheavals, Palaeogeogr. Palaeoecol., 252, 93-117, 2007.

Ovtcharova, M., Bucher, H., Schaltegger, U., Galfetti, T., Brayard, A., and Guex, J.: New Early to Middle Triassic U-Pb ages from South China: calibration with ammonoid biochronozones and implications for the timing of the Triassic biotic recovery, Earth Planet. Sc. Lett., 243, 463-475, 2006.

Pakhomova, S. V., Hall, P. O., Kononets, M. Y., Rozanov, A. G., Tengberg, A., and Vershinin, A. V.: Fluxes of iron and manganese across the sediment-water interface under various redox conditions, Mar. Chem., 107, 319-331, 2007.

Payne, J. L., Lehrmann, D. J., Wei, J. Y., Orchard, M. J., Schrag, D. P., and Knoll, A. H.: Large perturbations of the carbon cycle during recovery from the end-Permian extinction, Science, 305, 506-509, 2004.

Price, J. R. and Velbel, M.: Chemical weathering indices applied to weathering profiles developed on heterogeneous felsic metamorphic parent rocks, Chem. Geol., 202, 397-416, 2003.

Reichow, M. K., Pringle, M. S., Al'Mukhamedov, A. I., Allen, M. B., Andreichev, V. L., Buslov, M. M., Davies, C. E., Fedoseev, G. S., Fitton, J. G., Inger, S., Medvedev, A. Y., Mitchell, C., Puchkov, V. N., Safonova, I. Y., Scott, R. A., and Saunders, A. D.: The timing and extent of the eruption of the Siberian Traps large igneous province: implications for the end-Permian environmental crisis, Earth Planet. Sc. Lett., 277, 9-20, 2009.

Renne, P. R., Zheng, Z. C., Richards, M. A., Black, M. T., and Basu, A. R.: Synchrony and causal relations between PermianTriassic boundary crisis and Siberian flood volcanism, Science, 269, 1413-1416, 1995.

Retallack, G. J. and Jahren, A. H.: Methane release from igneous intrusion of coal during Late Permian extinction events, J. Geol., 116, 1-20, 2008.

Retallack, G. J., Sheldon, N. D, Carr, P. F., Fanning, M., Thompson, C. A., Williams, M. L., Jones, B. G., and Hutton, A.: Multiple Early Triassic greenhouse crises impeded recovery from Late Permian mass extinction, Palaeogeogr. Palaeoecol., 308, 233251, 2011. 
Rind, D.: Latitudinal temperature gradients and climate change, J. Geophys. Res., 103, 5943-5971, 1998.

Romano, C., Goudemand, N., Vennemann, T. W., Ware, D., Schneebeli-Hermann, E., Hochuli, P. A., Brühwiler, T., Brinkmann, W., and Bucher, H.: Climatic and biotic upheavals following the end-Permian mass extinction, Nat. Geosci., 6, 5760, 2013.

Rue, E. L., Smith, G. J., Cutter, G. A., and Bruland, K. W.: The response of trace element redox couples to suboxic conditions in the water column, Deep-Sea Res. Pt. I, 44, 113-134, 1997.

Saito, R., Kaiho, K., Oba, M., Takahashi, S., Chen, Z. Q., and Tong, J .N.: A terrestrial vegetation turnover in the middle of the Early Triassic, Global Planet. Change, 105, 152-159, 2013.

Shen, J. W. and Xu, X. L.: Microbial carbonates as contributors to Upper Permian (Guadalupian-Lopingian) biostromes and reefs in carbonate platform margin setting, Ziyuan County, South China, Palaeogeogr. Palaeocl., 218, 217-238, 2005.

Shen, Y. N.: C-isotope variations and paleoceanographic changes during the late Neoproterozoic on the Yangtze Platform, China, Prec. Res., 113, 121-133, 2002.

Sholkovitz, E. and Shen, G. T.: The incorporation of rare earth elements in modern coral, Geochim. Cosmochim. Ac., 59, 2749 2756, 1995.

Song, H. J., Wignall, P. B., Chen, Z. Q., Tong, J. N., Bond, D. P., Lai, X. L., Zhao, X. M., Jiang, H. S., Yan, C. B., and Niu, Z. J.: Recovery tempo and pattern of marine ecosystems after the end-Permian mass extinction, Geology, 39, 739-742, 2011.

Song, H. Y., Tong, J. N., Algeo, T. J., Horacek, M., Qiu, H. O., Song, H. J., Tian, L., and Chen, Z. Q.: Large vertical $\delta^{13} \mathrm{C}_{\text {DIC }}$ gradients in Early Triassic seas of the South China craton: Implications for oceanographic changes related to Siberian Traps volcanism, Global Planet. Change, 105, 7-20, 2013.

Song, H. Y., Tong, J. N., Algeo, T. J., Song, H. J., Qiu, H. O., Zhu, Y. Y., Tian, L., Bates, S., Lyons, T. W., and Luo, G. M.: Early Triassic seawater sulfate drawdown, Geochim. Cosmochim. Ac., 128, 95-113, 2014.

Stanley, S. M.: Evidence from ammonoids and conodonts for multiple Early Triassic mass extinctions, P. Natl. Acad. Sci. USA, 106, 15264-15267, 2009.

Sun, Y. D., Joachimski, M. M., Wignall, P. B., Yan, C. B., Chen, Y. L., Jiang, H. S., Wang, L. N., and Lai, X. L.: Lethally hot temperatures during the Early Triassic greenhouse, Science, 338, 366-370, 2012.
Tong, J. N., Zuo, J. X., and Chen, Z. Q.: Early Triassic carbon isotope excursions from South China: proxies for devastation and restoration of marine ecosystems following the end-Permian mass extinction, Geol. J., 42, 371-389, 2007.

Webb, G. E., Nothdurft, L. D., Kamber, B. S., Kloprogge, J., and Zhao, J. X.: Rare earth element geochemistry of scleractinian coral skeleton during meteoric diagenesis: a sequence through neomorphism of aragonite to calcite, Sedimentology, 56, 14331463, 2009.

Wignall, P. B. and Myers, K. J.: Interpreting benthic oxygen levels in mudrocks: a new approach, Geology, 16, 452-455, 1988.

Wright, J., Schrader, H., and Holser, W. T.: Paleoredox variations in ancient oceans recorded by rare earth elements in fossil apatite, Geochim. Cosmochim. Ac., 51, 631-644, 1987.

Wu, Y. S., Jiang, H. X., and Fan, J. S.: Evidence for sea-level falls in the Permian-Triassic transition in the Ziyun area, South China, Geol. J., 45, 170-185, 2010.

Yin, H. F. and Tong, J. N.: Late Permian-Middle Triassic sea level changes of Yangtze Platform, Jour. China Univ. Geosci.-Wuhan, 7, 101-104, 1996.

Yin, H. F., Jiang, H. S., Xia, W. C., Feng, Q. L., Zhang, N., and Shen, J.: The end-Permian regression in South China and its implication on mass extinction, Earth-Sci. Rev., 137, 19-33, 2014.

Zakharov, Y. D. and Popov, A. M.: Recovery of brachiopod and ammonoid faunas following the end-Permian crisis: additional evidence from the Lower Triassic of the Russian Far East and Kazakhstan, J. Earth Sci., 25, 1-44, 2014.

Zhao, L. S., Orchard, M. J., Tong, J. N., Sun, Z. I., Zuo, J. X., Zhang, S. X., and Yun, A. L.: Lower Triassic conodont sequence in Chaohu, Anhui Province, China and its global correlation, Palaeogeogr. Palaeoecol., 252, 24-38, 2007.

Zhao, L. S., Chen, Z. Q., Algeo, T. J., Chen, J., Chen, Y., Tong, J., Gao, S., Zhou, L., Hu, Z., and Liu, Y.: Rare-earth element patterns in conodont albid crowns: Evidence for massive inputs of volcanic ash during the latest Permian biocrisis?, Global Planet. Change, 105, 135-151, 2013.

Zhao, Y. Y. and Zheng, Y. F.: Diagenesis of carbonate sediments, Acta Petrol. Sin., 27, 501-519, 2011. 